\title{
Comparative Advantage and Trade Specialization of East Asian Countries: Do East Asian Countries Specialize on Product Groups with High Comparative Advantage?
}

\author{
Eva Ervani ${ }^{1}$, Tri Widodo ${ }^{2} \&$ Muhammad Edhie Purnawan ${ }^{3}$ \\ ${ }^{1}$ Doctoral Program, Faculty of Economics and Business, Universitas Gadjah Mada, Indonesia; and Faculty of \\ Economics and Business, Padjadjaran University, Jl. Dipati Ukur No.35, Bandung, Indonesia \\ ${ }^{2}$ Center for Southeast Asian Social Studies (CESASS); and Faculty of Economics and Business, Gadjah Mada \\ University, Jl. Humaniora No.1, Bulaksumur, Yogyakarta, Indonesia \\ ${ }^{3}$ Faculty of Economics and Business, Gadjah Mada University, Jl. Humaniora No.1, Bulaksumur, Yogyakarta, \\ Indonesia \\ Correspondence: Eva Ervani, Doctoral Program, Faculty of Economics and Business, Universitas Gadjah Mada, \\ Indonesia; and Faculty of Economics and Business, Padjadjaran University, Jl. Dipati Ukur No.35, Bandung, \\ Indonesia.
}

Received: May 28, 2018

doi:10.5539/ibr.v12n2p113
Accepted: January 14, $2019 \quad$ Online Published: January 21, 2019

URL: https://doi.org/10.5539/ibr.v12n2p113

\begin{abstract}
This paper analyzes whether East Asian countries (Indonesia, China, Japan, Hong Kong, South Korea, and Singapore) specialize on product groups with high comparative advantage. We use the data on the 3-digit SITC Revision 2 for 237 product groups published by the UN-COMTRADE. Firstly, we calculate the Revealed Symmetric Comparative Advantage (RSCA) index to know the product groups with high comparative advantage from each the East Asian countries. Secondly, we calculate the export share to know the trade specialization of product groups from each the East Asian countries. Thirdly, we compare between the product groups included in top-twenty SITC of comparative advantage with top-twenty SITC of trade specialization from each the East Asian countries. This paper concludes that throughout the study periods of 1995, 2005, and 2015, East Asian countries (Indonesia, China, Japan, Hong Kong, South Korea, and Singapore) specialize on product groups with low comparative advantage. It was also found that product classification dominating the comparative advantage and trade specialization of East Asian countries was the technology intensive products classification.
\end{abstract}

\section{JEL classification: F10, F14, F17}

Keywords: comparative advantage, export share, RSCA, trade specialization

\section{Introduction}

Comparative advantage is the advantage that a country obtains in specializing to produce products that have relatively lower prices than in other countries. Comparative advantage is usually used as an indicator to measure the performance and competitiveness of international trade. In comparative advantage condition, a country in a competitive condition will specialize in producing and exporting goods. Minondo (2011) found that products of comparative advantage of a country play a very important role in explaining the level of export diversification. While Laursen (1998) found that RSCA is the best measurement in measuring comparative advantage.

In international trade theory, comparative advantage is an important concept in explaining the trade patterns. The concept of comparative advantage was introduced by David Ricardo (1817) with the rigid assumptions then known as the Ricardian model. In modern international trade theory, these assumptions are made more realistic. According to traditional international trade theory, a country will export goods that have comparative advantage and will import goods that have no comparative advantage (comparative disadvantage).

The high economic development in East Asia shows the ability of production from East Asian countries in producing manufactured products and capability in developing industrial production. In this study, the countries analyzed are the East Asian countries. Based on the World Bank classification and geographically region includes Indonesia, China, Japan, Hong Kong, South Korea (Republic of Korea) and Singapore. The selection of 
East Asian countries in this study is based on several reasons. First, the East Asian countries have succeeded in creating a very high export and excellent leading exporters such as Japan, China, South Korea, Hong Kong, and Singapore. The spectacular export of these countries mostly based on government support in planning the economy and promoting the sectors of export industry as a pillar of the economy. Second, the successes of Hong Kong, South Korea and Singapore in changing the economic structure from unskilled-labor intensive production to skilled-labor intensive production and eventually became capital-intensive production, so these countries became pioneers in shifting the export focus from primary commodities into manufactured products. Third, trade expansion for the Asian region is geographically concentrated in the East Asia especially in Japan and China. Fourth, Hong Kong, South Korea, and Singapore are examples of successful countries in export promotion strategies as well as the earliest countries adopted export promotion strategy. Figure 1 shows the trend of comparative advantage of East Asian countries during the period 1995-2015.

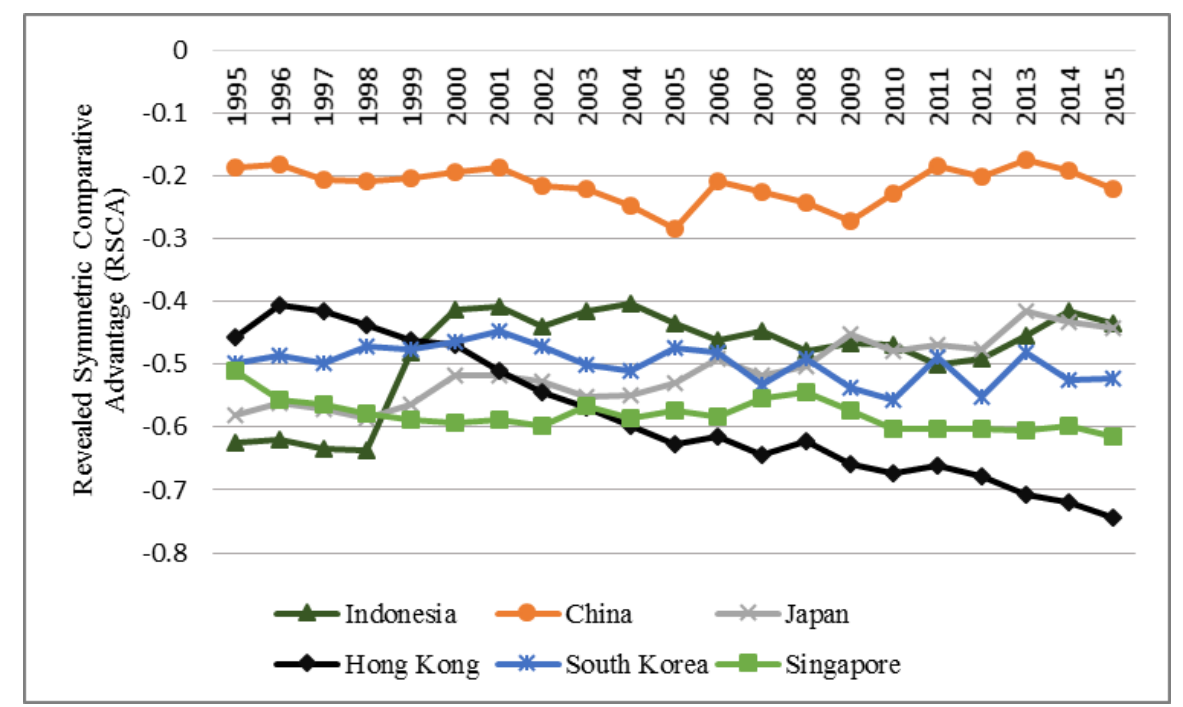

Figure 1. Trends of Comparative Advantages from East Asian Countries, 1995-2015

Source: UN-COMTRADE 3-digit SITC Revision 2. Authors' calculations.

China in the period 1995-2015 is a country that has the highest comparative advantage compared to Indonesia, Japan, Hong Kong, South Korea, and Singapore. Hong Kong is a country that has a trend of comparative advantage that continues to decline from the period 1996-2015 and the lowest comparative advantage in the period 2004-2015. In the period 1995-1999, comparative advantage of Hong Kong was higher than South Korea, Japan, Singapore, and Indonesia. While Japan in 1995-2015 has a trend of comparative advantage that continues to increase. The trend of Indonesia's comparative advantage in the period 1995-1998 was the lowest but it had experienced a very sharp and significant increase in 1998-2000 and then in 2000-2015 tended to be flat but still high from South Korea, Singapore and Hong Kong. While South Korea and Singapore during the period 1995-2015 have a trend of comparative advantage that tends to flat. The trend of South Korea's comparative advantage is higher than the trend of Singapore's comparative advantage.

In this study, the authors want to know the export products that become a comparative advantage and trade specialization of the East Asian countries. This study investigates whether East Asian countries (Indonesia, China, Japan, Hong Kong, South Korea, and Singapore) specialize on product groups with high comparative advantage. The rest of this paper is organized as follows. The second section describes the literature review about the comparative advantage and trade specialization. The third section describes the methodology that consists of data and analytical tools that are used. The fourth section discusses the results and analysis of comparative advantage, trade specialization, and comparison between the product groups included in top-twenty SITC of comparative advantage with top-twenty SITC of trade specialization from each the East Asian countries, then the fifth section discusses the conclusions of this research.

\section{Literature Review}

As a solution to the weakness of absolute advantage theory of Adam Smith, David Ricardo (1817) introduced the comparative advantage theory. Not all countries have an absolute advantage or absolute advantage is owned by only one country. Comparative advantage theory of David Ricardo mentions that the country will export 
products that have a comparative advantage. Comparative advantage is the advantage that a country gets in specializing to produce products that have a relatively lower price than in other country. The principle of comparative advantage states that a country in a competitive condition will specialize in producing and exporting goods at the lowest relative cost.

Previous studies of comparative advantage and trade specialization are research conducted by Balassa (1977) which analyzes the patterns of comparative advantage of manufactured products from major industrialized countries (United States, Canada, European Common Market, United Kingdom, Sweden, and Japan) using RCA. In his research, Balassa (1977) states that the increased in specialization and diversification of manufactured exports depends on a variety of factors namely the size of the domestic market, the rate of technological development, natural resources, and the impact of economic integration. The results of the analysis show that the industrialized countries tend to have high export diversification. The presence of the European Common Market contributes to the increased diversification of manufacturing exports of its member countries. Balassa and Noland (1989) examined the comparative advantages of Japan and the United States for 57 primary products and 167 manufactured products using the RCA index. Testing is done by calculating the relative export share index and net export ratio. The results show that between 1967 and 1985 there was an increase in Japanese specialization on human-capital intensive products while United States increased specialization in natural-resource intensive products. Research conducted by Widodo (2009) is to examine the changes of dynamic comparative advantage of ASEAN countries, China, Republic of Korea, and Japan (ASEAN+3) using RSCA index. The results show that there is a change in the pattern of comparative advantage of ASEAN+3 countries. The increase in overall comparative advantage is supported by the high increase in comparative advantage of product groups that had a low comparative advantage in the past. The pattern of comparative advantage of ASEAN countries is similar to the pattern of Japan's comparative advantage. The catching-up process is supported by changes in the pattern of comparative advantages in both ASEAN and Japan in terms of Japan's foreign direct investment (FDI) in ASEAN countries. Then the study conducted by Phuong (2010) is to analyze the comparative advantages of Vietnam and its changes using RCA. Implemented since the implementation of state reform program that is starting in 1986. The data used in this study is International Economics Databank (IEDB) and United Nations Statistical Division (UNSD). The results show that Vietnam's largest comparative advantage is based on the ownership of labor and natural resources. Therefore, that Vietnam is able to develop its exports with the condition of this wealth.

\section{Methodology}

\subsection{Data}

The author uses international trade data published by United Nations Commodity Trade Statistics Database (UN-COMTRADE) on 3-digit SITC revised 2 for 237 product groups. In this research, there are 2 product groups which are not included in the analysis because the data are not available, namely SITC 675 (Hoop and strip of iron or steel, hot-rolled or cold-rolled) and SITC 911 (Postal packages not classified according to kind). The countries analyzed in this study consist of six countries that refer to the World Bank classification and geographically located in the East Asia region i.e. Indonesia, China, Japan, Hong Kong, South Korea, and Singapore.

\subsection{RSCA and Export Share}

In this study, following Laursen (1998) and Widodo (2009), the authors use the RSCA (Revealed Symmetric Comparative Advantage) index to measure the comparative advantage of East Asian countries (Indonesia, China, Japan, Hong Kong, South Korea, and Singapore). The RSCA index has a range $-1 \leq$ RSCA $\leq 1$ which will give a symmetrical value. An export commodity of a country that has the RSCA value greater than zero, then these commodities have comparative advantage. If the value of RSCA is less than zero, then the country has no comparative advantage for the commodity. In this study, the authors use the RCA index from Vollrath (1991) and the RSCA index from Laursen (1998) with the following formula:

$$
\begin{aligned}
& R C A_{i j}=\frac{\left(x_{i j} / X_{T j}\right)}{\left(X_{i w}-X_{i j}\right) /\left(x_{T w}-X_{T j}\right)} \\
& R S C A_{i j}=\left(R C A_{i j}-1\right) /\left(R C A_{i j}+1\right)
\end{aligned}
$$

Following Hinloopen and Marrewijk (2005), the level of export specialization is the export share which calculating the percentage of export value of a product group (SITC) of a country to the total export value of that country. 


$$
\text { Export Share }=\left(\mathrm{X}_{\mathrm{ij}} / \mathrm{X}_{\mathrm{Tj}}\right) \times 100
$$

where $\mathrm{RCA}_{\mathrm{ij}}$ denotes revealed comparative advantage for group of products (SITC) $\mathrm{i}$ from country $\mathrm{j}$; $\mathrm{RSCA}_{\mathrm{ij}}$ denotes revealed symmetric comparative advantage for group of products (SITC) i from country $\mathrm{j} ; \mathrm{X}_{\mathrm{ij}}$ represents exports for group of products (SITC) $\mathrm{i}$ from country $\mathrm{j} ; \mathrm{X}_{\mathrm{Tj}}$ represents total exports from country $\mathrm{j}$; $\mathrm{X}_{\mathrm{iw}}$ represents the world exports for group of products (SITC) $\mathrm{i}$; and $\mathrm{X}_{\mathrm{Tw}}$ represents the world total exports.

Higher value of export share indicate that the product group is produced in greater proportion than other product groups. The higher the export share value of a product group the higher the trade specialization of that product group in a country compared to other product groups in that country.

Then to find out whether a country specializes in a product groups with high comparative advantage or specializes in a product groups with low comparative advantage is examined by comparing between the product groups included in the top-twenty SITC of comparative advantage with the top-twenty SITC of export share of the country concerned. If the top-twenty SITC of comparative advantages of a country are all become trade specialization from that country, it indicates that the country specializes in a product group that has a high comparative advantage. If the top-twenty SITC of comparative advantages of a country are not all (in part) become trade specialization, it indicates that the country specializes in product group which comparative advantage is low.

The skewness value of RSCA from a country at time $t$ is negative, indicates that the country is more specialized in products with high comparative advantage. In contrast, the RSCA skewness coefficient of a country at time t is positive, indicates that the country is more specialized in products with low comparative advantage. The RSCA skewness formula (Karl Person) is:

$$
S k_{R S C A_{j, t}}=\frac{3\left(\operatorname{mean}_{R S C A_{j, t}}-\text { median }_{R S C A_{j, t}}\right)}{s t d e v_{R S C A_{j, t}}}
$$

SkRSCA $_{j, t}$ is the skewness coefficient of RSCA variable (Karl Person formula) for country $j$ at time t.

\section{Results and Discussion}

\subsection{Comparative Advantage of East Asian Countries}

Comparative advantage of East Asian countries is determined by calculating the RSCA index value of each East Asian country (Indonesia, China, Japan, Hong Kong, South Korea, and Singapore) using UN-Comtrade data on 3-digit SITC Revision 2 for 237 product groups in 1995, 2005 and 2015. The higher of RSCA index value from a product group, the higher of comparative advantage from that product group in a country compared to the other product groups in that country. After calculating the RSCA index value of 237 SITC, then it is ranked based on the value of the RSCA index and selected twenty SITC with the highest RSCA value as the comparative advantage products of the country concerned. To simplify the interpretation of the results of the comparative advantage analysis, the authors classified 237 SITC into 6 product classifications based on the classification of Empirical Trade Analysis (ETA), see Appendix A. Table 1-6 shows the changes in comparative advantage of each East Asian country that shown through products that include on top-twenty SITC of comparative advantages in 1995, 2005, and 2015 using the UN-Comtrade data on 3-digit SITC Revision 2 for 237 product groups.

Table 1. Top-Twenty SITC of Indonesia Comparative Advantage 1995, 2005, and 2015

\begin{tabular}{ccclc}
\hline Year & Rank & SITC & \multicolumn{1}{c}{ Commodity } & RSCA \\
\hline 1995 & 1 & S2-232 & Natural rubber latex; rubber and gums & 0.95 \\
& 2 & S2-634 & Veneers, plywood, "improved" wood and other wood, worked & 0.95 \\
& 3 & S2-687 & Tin & 0.90 \\
& 4 & S2-341 & Gas, natural and manufactured & 0.90 \\
& 5 & S2-075 & Spices & 0.89 \\
& 6 & S2-245 & Fuel wood and wood charcoal & 0.89 \\
& 7 & S2-424 & Other fixed vegetable oils, fluid or solid, crude, refined & 0.88 \\
& 8 & S2-287 & Ores and concentrates of base metals & 0.85 \\
& 9 & S2-431 & Animal and vegetable oils and fats, processed, and waxes & 0.79 \\
10 & S2-072 & Cocoa & 0.78 \\
& 11 & S2-036 & Crustaceans and molluscs, fresh, chilled, frozen, salted, etc & 0.78 \\
12 & S2-635 & Wood manufactures & 0.74 \\
& 13 & S2-322 & Coal, lignite and peat & 0.73 \\
14 & S2-851 & Footwear & 0.69 \\
& 15 & S2-074 & Tea and mate & 0.68
\end{tabular}




\begin{tabular}{|c|c|c|c|c|}
\hline & 16 & S2-071 & Coffee and coffee substitutes & 0.65 \\
\hline & 17 & S2-844 & Under garments of textile fabrics, not knitted or crocheted & 0.62 \\
\hline & 18 & S2-333 & Crude petroleum and oils obtained from bituminous minerals & 0.62 \\
\hline & 19 & S2-653 & Fabrics, woven, of man-made fibres (not narrow or special fabrics) & 0.58 \\
\hline & 20 & S2-763 & Gramophones, dictating machines and other sound recorders & 0.56 \\
\hline \multirow[t]{20}{*}{2005} & 1 & S2-424 & Other fixed vegetable oils, fluid or solid, crude, refined & 0.97 \\
\hline & 2 & S2-687 & Tin & 0.96 \\
\hline & 3 & $\mathrm{~S} 2-232$ & Natural rubber latex; rubber and gums & 0.95 \\
\hline & 4 & $\mathrm{~S} 2-322$ & Coal, lignite and peat & 0.85 \\
\hline & 5 & S2-287 & Ores and concentrates of base metals & 0.83 \\
\hline & 6 & S2-072 & Cocoa & 0.82 \\
\hline & 7 & S2-634 & Veneers, plywood, "improved" wood and other wood, worked & 0.81 \\
\hline & 8 & S2-075 & Spices & 0.74 \\
\hline & 9 & S2-341 & Gas, natural and manufactured & 0.74 \\
\hline & 10 & S2-036 & Crustaceans and molluscs, fresh, chilled, frozen, salted, etc & 0.73 \\
\hline & 11 & $\mathrm{~S} 2-245$ & Fuel wood and wood charcoal & 0.71 \\
\hline & 12 & S2-431 & Animal and vegetable oils and fats, processed, and waxes & 0.71 \\
\hline & 13 & S2-091 & Margarine and shortening & 0.69 \\
\hline & 14 & S2-267 & Other man-made fibres suitable for spinning, and waste & 0.67 \\
\hline & 15 & S2-651 & Textile yarn & 0.66 \\
\hline & 16 & S2-844 & Under garments of textile fabrics, not knitted or crocheted & 0.65 \\
\hline & 17 & S2-635 & Wood manufactures & 0.64 \\
\hline & 18 & S2-251 & Pulp and waste paper & 0.63 \\
\hline & 19 & S2-071 & Coffee and coffee substitutes & 0.61 \\
\hline & 20 & S2-074 & Tea and mate & 0.61 \\
\hline \multirow[t]{20}{*}{2015} & 1 & S2-424 & Other fixed vegetable oils, fluid or solid, crude, refined & 1.00 \\
\hline & 2 & S2-232 & Natural rubber latex; rubber and gums & 0.98 \\
\hline & 3 & S2-687 & Tin & 0.96 \\
\hline & 4 & $\mathrm{~S} 2-322$ & Coal, lignite and peat & 0.95 \\
\hline & 5 & S2-431 & Animal and vegetable oils and fats, processed, and waxes & 0.93 \\
\hline & 6 & S2-245 & Fuel wood and wood charcoal & 0.91 \\
\hline & 7 & S2-091 & Margarine and shortening & 0.87 \\
\hline & 8 & S2-075 & Spices & 0.87 \\
\hline & 9 & S2-634 & Veneers, plywood, "improved" wood and other wood, worked & 0.85 \\
\hline & 10 & S2-267 & Other man-made fibres suitable for spinning, and waste & 0.80 \\
\hline & 11 & S2-072 & Cocoa & 0.79 \\
\hline & 12 & S2-289 & Ores and concentrates of precious metals, waste, scrap & 0.70 \\
\hline & 13 & S2-036 & Crustaceans and molluscs, fresh, chilled, frozen, salted, etc & 0.70 \\
\hline & 14 & S2-651 & Textile yarn & 0.69 \\
\hline & 15 & S2-071 & Coffee and coffee substitutes & 0.68 \\
\hline & 16 & S2-287 & Ores and concentrates of base metals & 0.68 \\
\hline & 17 & S2-037 & Fish, crustaceans and molluscs, prepared or preserved & 0.65 \\
\hline & 18 & S2-251 & Pulp and waste paper & 0.64 \\
\hline & 19 & S2-341 & Gas, natural and manufactured & 0.63 \\
\hline & 20 & $\mathrm{~S} 2-851$ & Footwear & 0.63 \\
\hline
\end{tabular}

Source: UN-COMTRADE SITC 3-digit Revision 2, author's calculation.

Based on table 1, the top-twenty comparative advantages of Indonesia in 1995 based on ETA classification are dominated by product groups which are included in the classification of primary products, there are 13 SITC i.e. SITC 232, 341, 075, 245, 424, 287, 431, 072, 036, 322, 074, 071, and 333. In 2005, Indonesia's comparative advantage was still dominated by product groups included in the classification of primary products with SITC increasing to 15 SITC i.e. SITC 424, 232, 322, 287, 072, 075, 341, $036,245,431,091,267,251,071$, and 074. From 1995 to 2005, Indonesia's comparative advantage changes in rank position and changes in product group composition where 3 new SITC emerged in 2005 were SITC 091, 267, 251 and 1 SITC were missing from the top-twenty comparative advantages of 1995 is SITC 333. Then in 2015 Indonesia's comparative advantage remained dominated by the classification of primary products with a larger proportion than in 2005 indicated by the increasing number of SITC to 16 SITC namely SITC 424, 232, 322, 431, 245, 091, 075, 267, 072, 289, 036, $071,287,037,251$, and 341 . From 2005 to 2015 there was also a change in rank position and product group composition where there were 2 new SITC that emerged in 2015 i.e. SITC 289, 037 and 1 SITC lost from top-twenty comparative advantage in 2005 that is SITC 074. So during the period 1995-2015, although the products classification of Indonesia's comparative advantage did not change, but there has been an increase in the number of SITC, changes in rank position and changes in product group composition. 
Table 2. Top-Twenty SITC of China Comparative Advantage 1995, 2005, and 2015

\begin{tabular}{|c|c|c|c|c|}
\hline Year & Rank & SITC & Commodity & RSCA \\
\hline \multirow[t]{20}{*}{1995} & 1 & S2-261 & Silk & 0.96 \\
\hline & 2 & S2-323 & Briquettes; coke and semi-coke; lignite or peat; retort carbon & 0.86 \\
\hline & 3 & S2-848 & Articles of apparel, clothing accessories, non-textile, headgear & 0.80 \\
\hline & 4 & S2-658 & Made-up articles, wholly or chiefly of textile materials & 0.77 \\
\hline & 5 & S2-291 & Crude animal materials & 0.77 \\
\hline & 6 & S2-831 & Travel goods, handbags etc, of leather, plastics, textile, others & 0.77 \\
\hline & 7 & S2-671 & Pig and sponge iron, spiegeleisen, etc, and ferro-alloys & 0.77 \\
\hline & 8 & S2-842 & Men's and boys' outerwear, textile fabrics not knitted or crocheted & 0.75 \\
\hline & 9 & S2-666 & Pottery & 0.75 \\
\hline & 10 & S2-844 & Under garments of textile fabrics, not knitted or crocheted & 0.74 \\
\hline & 11 & S2-572 & Explosives and pyrotechnic products & 0.73 \\
\hline & 12 & S2-843 & Womens, girls, infants outerwear, textile, not knitted or crocheted & 0.72 \\
\hline & 13 & S2-689 & Miscellaneous non-ferrous base metals, employed in metallurgy & 0.72 \\
\hline & 14 & S2-687 & Tin & 0.71 \\
\hline & 15 & S2-652 & Cotton fabrics, woven (not including narrow or special fabrics) & 0.71 \\
\hline & 16 & S2-851 & Footwear & 0.70 \\
\hline & 17 & S2-074 & Tea and mate & 0.69 \\
\hline & 18 & S2-056 & Vegetables, roots and tubers, prepared or preserved & 0.68 \\
\hline & 19 & S2-899 & Other miscellaneous manufactured articles & 0.68 \\
\hline & 20 & S2-894 & Baby carriages, toys, games and sporting goods & 0.68 \\
\hline \multirow[t]{20}{*}{2005} & 1 & S2-261 & Silk & 0.96 \\
\hline & 2 & S2-323 & Briquettes; coke and semi-coke; lignite or peat; retort carbon & 0.77 \\
\hline & 3 & S2-848 & Articles of apparel, clothing accessories, non-textile, headgear & 0.77 \\
\hline & 4 & S2-666 & Pottery & 0.76 \\
\hline & 5 & S2-763 & Gramophones, dictating machines and other sound recorders & 0.72 \\
\hline & 6 & S2-658 & Made-up articles, wholly or chiefly of textile materials & 0.72 \\
\hline & 7 & S2-894 & Baby carriages, toys, games and sporting goods & 0.70 \\
\hline & 8 & S2-831 & Travel goods, handbags etc, of leather, plastics, textile, others & 0.70 \\
\hline & 9 & S2-751 & Office machines & 0.70 \\
\hline & 10 & S2-786 & Trailers, and other vehicles, not motorized & 0.69 \\
\hline & 11 & S2-851 & Footwear & 0.69 \\
\hline & 12 & S2-696 & Cutlery & 0.67 \\
\hline & 13 & S2-845 & Outerwear knitted or crocheted, not elastic nor rubberized & 0.66 \\
\hline & 14 & S2-752 & Automatic data processing machines and units thereof & 0.66 \\
\hline & 15 & S2-871 & Optical instruments and apparatus & 0.63 \\
\hline & 16 & S2-847 & Clothing accessories, of textile fabrics & 0.63 \\
\hline & 17 & S2-689 & Miscellaneous non-ferrous base metals, employed in metallurgy & 0.61 \\
\hline & 18 & S2-842 & Men's and boys' outerwear, textile fabrics not knitted or crocheted & 0.61 \\
\hline & 19 & S2-697 & Household equipment of base metal & 0.61 \\
\hline & 20 & S2-844 & Under garments of textile fabrics, not knitted or crocheted & 0.61 \\
\hline \multirow[t]{20}{*}{2015} & 1 & S2-261 & Silk & 0.93 \\
\hline & 2 & S2-666 & Pottery & 0.88 \\
\hline & 3 & S2-812 & Sanitary, plumbing, heating, lighting fixtures and fittings & 0.75 \\
\hline & 4 & S2-658 & Made-up articles, wholly or chiefly of textile materials & 0.70 \\
\hline & 5 & S2-653 & Fabrics, woven, of man-made fibres (not narrow or special fabrics) & 0.70 \\
\hline & 6 & S2-845 & Outerwear knitted or crocheted, not elastic nor rubberized & 0.70 \\
\hline & 7 & S2-697 & Household equipment of base metal & 0.70 \\
\hline & 8 & S2-652 & Cotton fabrics, woven (not including narrow or special fabrics) & 0.69 \\
\hline & 9 & S2-831 & Travel goods, handbags etc, of leather, plastics, textile, others & 0.69 \\
\hline & 10 & S2-851 & Footwear & 0.68 \\
\hline & 11 & S2-894 & Baby carriages, toys, games and sporting goods & 0.67 \\
\hline & 12 & S2-847 & Clothing accessories, of textile fabrics & 0.67 \\
\hline & 13 & S2-655 & Knitted or crocheted fabrics (including tubular, etc, fabrics) & 0.65 \\
\hline & 14 & S2-752 & Automatic data processing machines and units thereof & 0.65 \\
\hline & 15 & S2-843 & Womens, girls, infants outerwear, textile, not knitted or crocheted & 0.64 \\
\hline & 16 & S2-842 & Men's and boys' outerwear, textile fabrics not knitted or crocheted & 0.62 \\
\hline & 17 & S2-764 & Telecommunication equipment, nes; parts and accessories & 0.61 \\
\hline & 18 & S2-763 & Gramophones, dictating machines and other sound recorders & 0.60 \\
\hline & 19 & S2-848 & Articles of apparel, clothing accessories, non-textile, headgear & 0.60 \\
\hline & 20 & S2-696 & Cutlery & 0.59 \\
\hline
\end{tabular}

Source: UN-COMTRADE 3-digit SITC Revision 2 Authors' calculations.

When viewed from the top-twenty of China's comparative advantage (table 2) in 1995, 2005, and 2015, China's comparative advantage is dominated by a group of products included in the unskilled-labor intensive products 
classification. In 1995, 10 SITC were SITC 848, 658, 831, 842, 666, 844, 843, 652, 851, and 894. In 2005, 10 SITC were SITC $848,666,658,894,831,851,845,847,842$, and 844 . In 2015 , it increased to 14 SITC namely SITC $666,812,658,653,845,652,831,851,894,847,655,843,842$, and 848. From 1995 to 2005 there was a change in the rank position and product group composition where 2 new SITC emerged in 2005 were SITC 845, 847 and 2 SITC lost from the top-twenty comparative advantages of 1995 i.e. SITC 843, 652. Changes in rank position and product group composition also occurred in 2005 to 2015, where there were 5 new SITC emerging in 2015 that SITC 812, 653, 652, 655, 843 and 1 SITC were missing from the top-twenty comparative advantage of 2005 i.e. SITC 844 . So for 20 years, although there is a change in rank position and product group composition but China's comparative advantage product group is still dominated by the unskilled-labor intensive products classification, which differ only the type of product group.

Table 3. Top-Twenty SITC of Japan Comparative Advantage 1995, 2005, and 2015

\begin{tabular}{|c|c|c|c|c|}
\hline Year & Rank & SITC & Commodity & RSCA \\
\hline \multirow[t]{20}{*}{1995} & 1 & $\mathrm{~S} 2-881$ & Photographic apparatus and equipment & 0.68 \\
\hline & 2 & S2-793 & Ships, boats and floating structures & 0.63 \\
\hline & 3 & S2-871 & Optical instruments and apparatus & 0.59 \\
\hline & 4 & S2-763 & Gramophones, dictating machines and other sound recorders & 0.56 \\
\hline & 5 & $\mathrm{~S} 2-751$ & Office machines & 0.53 \\
\hline & 6 & $\mathrm{~S} 2-736$ & Metalworking machine-tools, parts and accessories thereof & 0.53 \\
\hline & 7 & $\mathrm{~S} 2-713$ & Internal combustion piston engines, and parts thereof & 0.51 \\
\hline & 8 & S2-882 & Photographic and cinematographic supplies & 0.51 \\
\hline & 9 & S2-884 & Optical goods & 0.47 \\
\hline & 10 & $\mathrm{~S} 2-776$ & Thermionic, microcircuits, transistors, valves, etc & 0.47 \\
\hline & 11 & $\mathrm{~S} 2-782$ & Lorries and special purposes motor vehicles & 0.44 \\
\hline & 12 & $\mathrm{~S} 2-737$ & Metalworking machinery (other than machine-tools), and parts & 0.42 \\
\hline & 13 & $\mathrm{~S} 2-712$ & Steam engines, turbines & 0.41 \\
\hline & 14 & $\mathrm{~S} 2-711$ & Steam boilers and auxiliary plant; and parts thereof & 0.40 \\
\hline & 15 & $\mathrm{~S} 2-724$ & Textile and leather machinery, and parts thereof & 0.39 \\
\hline & 16 & $\mathrm{~S} 2-728$ & Other machinery, equipment, for specialized industries; parts & 0.39 \\
\hline & 17 & S2-781 & Passenger motor vehicles (excluding buses) & 0.38 \\
\hline & 18 & $\mathrm{~S} 2-895$ & Office and stationary supplies & 0.38 \\
\hline & 19 & $\mathrm{~S} 2-778$ & Electrical machinery and apparatus & 0.37 \\
\hline & 20 & S2-674 & Universals, plates, and sheets, of iron or steel & 0.36 \\
\hline \multirow[t]{20}{*}{2005} & 1 & $\mathrm{~S} 2-712$ & Steam engines, turbines & 0.75 \\
\hline & 2 & $\mathrm{~S} 2-881$ & Photographic apparatus and equipment & 0.72 \\
\hline & 3 & S2-882 & Photographic and cinematographic supplies & 0.68 \\
\hline & 4 & $\mathrm{~S} 2-884$ & Optical goods & 0.67 \\
\hline & 5 & $\mathrm{~S} 2-785$ & Cycles, scooters, motorized or not; invalid carriages & 0.67 \\
\hline & 6 & $\mathrm{~S} 2-736$ & Metalworking machine-tools, parts and accessories thereof & 0.63 \\
\hline & 7 & S2-763 & Gramophones, dictating machines and other sound recorders & 0.58 \\
\hline & 8 & $\mathrm{~S} 2-728$ & Other machinery, equipment, for specialized industries; parts & 0.57 \\
\hline & 9 & S2-793 & Ships, boats and floating structures & 0.54 \\
\hline & 10 & $\mathrm{~S} 2-711$ & Steam boilers and auxiliary plant; and parts thereof & 0.53 \\
\hline & 11 & $\mathrm{~S} 2-781$ & Passenger motor vehicles (excluding buses) & 0.52 \\
\hline & 12 & $\mathrm{~S} 2-723$ & Civil engineering, contractors' plant and equipment and parts & 0.44 \\
\hline & 13 & $\mathrm{~S} 2-737$ & Metalworking machinery (other than machine-tools), and parts & 0.43 \\
\hline & 14 & $\mathrm{~S} 2-713$ & Internal combustion piston engines, and parts thereof & 0.42 \\
\hline & 15 & $\mathrm{~S} 2-778$ & Electrical machinery and apparatus & 0.40 \\
\hline & 16 & $\mathrm{~S} 2-511$ & Hydrocarbons, nes, and derivatives & 0.40 \\
\hline & 17 & S2-266 & Synthetic fibres suitable for spinning & 0.40 \\
\hline & 18 & $\mathrm{~S} 2-724$ & Textile and leather machinery, and parts thereof & 0.38 \\
\hline & 19 & $\mathrm{~S} 2-722$ & Tractors (other than those falling in heading 74411 and 7832) & 0.38 \\
\hline & 20 & $\mathrm{~S} 2-674$ & Universals, plates, and sheets, of iron or steel & 0.37 \\
\hline \multirow[t]{12}{*}{2015} & 1 & S2-882 & Photographic and cinematographic supplies & 0.80 \\
\hline & 2 & $\mathrm{~S} 2-712$ & Steam engines, turbines & 0.77 \\
\hline & $\overline{3}$ & $\mathrm{~S} 2-584$ & Regenerated cellulose; derivatives of cellulose; vulcanized fibre & 0.69 \\
\hline & 4 & $\mathrm{~S} 2-736$ & Metalworking machine-tools, parts and accessories thereof & 0.67 \\
\hline & 5 & S2-267 & Other man-made fibres suitable for spinning, and waste & 0.65 \\
\hline & 6 & $\mathrm{~S} 2-728$ & Other machinery, equipment, for specialized industries; parts & 0.59 \\
\hline & 7 & S2-672 & Ingots and other primary forms, of iron or steel & 0.58 \\
\hline & 8 & S2-781 & Passenger motor vehicles (excluding buses) & 0.56 \\
\hline & 9 & $\mathrm{~S} 2-511$ & Hydrocarbons, nes, and derivatives & 0.55 \\
\hline & 10 & $\mathrm{~S} 2-676$ & Rails and railway track construction materials, of iron or steel & 0.54 \\
\hline & 11 & S2-266 & Synthetic fibres suitable for spinning & 0.53 \\
\hline & 12 & S2-233 & Synthetic rubber, latex, etc; waste, scrap of unhardened rubber & 0.53 \\
\hline
\end{tabular}




$\begin{array}{llll}13 & \text { S2-884 } & \text { Optical goods } & 0.51 \\ 14 & \text { S2-723 } & \text { Civil engineering, contractors' plant and equipment and parts } & 0.49 \\ 15 & \text { S2-674 } & \text { Universals, plates, and sheets, of iron or steel } & 0.43 \\ 16 & \text { S2-737 } & \text { Metalworking machinery (other than machine-tools), and parts } & 0.43 \\ 17 & \text { S2-713 } & \text { Internal combustion piston engines, and parts thereof } & 0.42 \\ 18 & \text { S2-282 } & \text { Waste and scrap metal of iron or steel } & 0.41 \\ 19 & \text { S2-663 } & \text { Mineral manufactures } & 0.40 \\ 20 & \text { S2-774 } & \text { Electro-medical and radiological equipment } & 0.39\end{array}$

Source: UN-COMTRADE 3-digit SITC Revision 2 Authors' calculations.

Table 3 reports that Japan's comparative advantage is dominated by products with the classification of technology intensive products. In 1995, there are 14 SITC i.e. SITC 881, 871, 751, 736, 713, 882, 884, 776, 737, $712,711,724,728$, and 778. In 2005, there are 14 SITC i.e. SITC 712, 881, 882, 884, 736, 728, 711, 723, 737, $713,778,511,724$, and 722 . Then in 2015 the number of SITC decreased to 11 SITC namely SITC 882, 712, 584, 736, 728, 511, 884, 723, 737, 713, and 774. From 1995 to 2005 there was a change in rank position and product group composition, there were 3 new SITC that emerged in 2005 i.e. SITC 723, 511, 722 and 3 SITC lost from top-twenty comparative advantage of 1995, namely SITC 871, 751, 776. In 2015 as well as in 2005, Japan's comparative advantage also experienced the dynamics of changes in rank position and product group composition, where there were 2 new SITC that emerged in 2015 i.e. SITC 584, 774 and 5 SITC missing from the top-twenty comparative advantages of 2005 i.e. SITC 881, 711, 778, 724, 722. So for 20 years, Japan did not experience a change in product classification of comparative advantage but changed its rank position and product group composition as well as decreasing the number of SITC where in 2015, there were 4 SITC classification of primary products did not exist in top-twenty comparative advantage of Japan in 1995.

Table 4. Top-Twenty SITC of Hong Kong Comparative Advantage 1995, 2005, and 2015

\begin{tabular}{|c|c|c|c|c|}
\hline Year & Rank & SITC & Commodity & RSCA \\
\hline \multirow[t]{20}{*}{1995} & 1 & S2-831 & Travel goods, handbags etc, of leather, plastics, textile, others & 0.85 \\
\hline & 2 & S2-885 & Watches and clocks & 0.81 \\
\hline & 3 & S2-894 & Baby carriages, toys, games and sporting goods & 0.81 \\
\hline & 4 & S2-261 & Silk & 0.75 \\
\hline & 5 & S2-762 & Radio-broadcast receivers & 0.74 \\
\hline & 6 & S2-851 & Footwear & 0.71 \\
\hline & 7 & S2-845 & Outerwear knitted or crocheted, not elastic nor rubberized & 0.70 \\
\hline & 8 & S2-655 & Knitted or crocheted fabrics (including tubular, etc, fabrics) & 0.67 \\
\hline & 9 & S2-899 & Other miscellaneous manufactured articles & 0.67 \\
\hline & 10 & S2-843 & Womens, girls, infants outerwear, textile, not knitted or crocheted & 0.64 \\
\hline & 11 & S2-844 & Under garments of textile fabrics, not knitted or crocheted & 0.64 \\
\hline & 12 & S2-652 & Cotton fabrics, woven (not including narrow or special fabrics) & 0.61 \\
\hline & 13 & S2-696 & Cutlery & 0.59 \\
\hline & 14 & S2-846 & Under-garments, knitted or crocheted & 0.59 \\
\hline & 15 & S2-848 & Articles of apparel, clothing accessories, non-textile, headgear & 0.58 \\
\hline & 16 & S2-277 & Natural abrasives & 0.56 \\
\hline & 17 & S2-881 & Photographic apparatus and equipment & 0.56 \\
\hline & 18 & S2-572 & Explosives and pyrotechnic products & 0.53 \\
\hline & 19 & S2-842 & Men's and boys' outerwear, textile fabrics not knitted or crocheted & 0.52 \\
\hline & 20 & S2-771 & Electric power machinery, and parts thereof & 0.52 \\
\hline \multirow[t]{19}{*}{2005} & 1 & S2-613 & Furskins, tanned or dressed; pieces of furskin, tanned or dressed & 0.88 \\
\hline & 2 & S2-885 & Watches and clocks & 0.82 \\
\hline & 3 & S2-212 & Furskins, raw & 0.80 \\
\hline & 4 & S2-831 & Travel goods, handbags etc, of leather, plastics, textile, others & 0.79 \\
\hline & 5 & S2-894 & Baby carriages, toys, games and sporting goods & 0.76 \\
\hline & 6 & S2-655 & Knitted or crocheted fabrics (including tubular, etc, fabrics) & 0.71 \\
\hline & 7 & S2-763 & Gramophones, dictating machines and other sound recorders & 0.70 \\
\hline & 8 & S2-845 & Outerwear knitted or crocheted, not elastic nor rubberized & 0.69 \\
\hline & 9 & S2-759 & Parts, nes of and accessories for machines of headings 751 or 752 & 0.68 \\
\hline & 10 & S2-611 & Leather & 0.68 \\
\hline & 11 & S2-771 & Electric power machinery, and parts thereof & 0.67 \\
\hline & 12 & S2-762 & Radio-broadcast receivers & 0.67 \\
\hline & 13 & S2-652 & Cotton fabrics, woven (not including narrow or special fabrics) & 0.63 \\
\hline & 14 & S2-897 & Gold, silver ware, jewelry and articles of precious materials & 0.61 \\
\hline & 15 & S2-843 & Womens, girls, infants outerwear, textile, not knitted or crocheted & 0.60 \\
\hline & 16 & S2-881 & Photographic apparatus and equipment & 0.57 \\
\hline & 17 & S2-851 & Footwear & 0.57 \\
\hline & 18 & S2-656 & Tulle, lace, embroidery, ribbons, trimmings and other small wares & 0.54 \\
\hline & 19 & S2-651 & Textile yarn & 0.52 \\
\hline
\end{tabular}




\begin{tabular}{lllll} 
& 20 & S2-846 & Under-garments, knitted or crocheted & 0.52 \\
\hline 2015 & 1 & S2-613 & Furskins, tanned or dressed; pieces of furskin, tanned or dressed & 0.81 \\
2 & S2-759 & Parts, nes of and accessories for machines of headings 751 or 752 & 0.74 \\
3 & S2-885 & Watches and clocks & 0.72 \\
4 & S2-971 & Gold, non-monetary (excluding gold ores and concentrates) & 0.70 \\
5 & S2-776 & Thermionic, microcircuits, transistors, valves, etc & 0.69 \\
6 & S2-764 & Telecommunication equipment, nes; parts and accessories & 0.69 \\
7 & S2-667 & Pearl, precious and semi-precious stones, unworked or worked & 0.67 \\
8 & S2-212 & Furskins, raw & 0.65 \\
9 & S2-771 & Electric power machinery, and parts thereof & 0.59 \\
10 & S2-883 & Cinematograph film, exposed and developed & 0.52 \\
11 & S2-656 & Tulle, lace, embroidery, ribbons, trimmings and other small wares & 0.50 \\
12 & S2-611 & Leather & 0.48 \\
13 & S2-772 & Electrical apparatus for making and breaking electrical circuits & 0.44 \\
14 & S2-831 & Travel goods, handbags etc, of leather, plastics, textile, others & 0.42 \\
15 & S2-894 & Baby carriages, toys, games and sporting goods & 0.41 \\
16 & S2-897 & Gold, silver ware, jewelry and articles of precious materials & 0.40 \\
17 & S2-655 & Knitted or crocheted fabrics (including tubular, etc, fabrics) & 0.37 \\
18 & S2-763 & Gramophones, dictating machines and other sound recorders & 0.34 \\
19 & S2-881 & Photographic apparatus and equipment & 0.33 \\
\hline & S2-884 & Optical goods &
\end{tabular}

Source: UN-COMTRADE 3-digit SITC Revision 2 Authors' calculations.

According to table 4, the top-twenty comparative advantages of Hong Kong in 1995 are dominated with unskilled-labor intensive products by 11 SITC i.e. SITC $831,894,851,845,655,843,844,652,846,848$, and 842. In 2005 is still dominated by 10 SITC unskilled-labor intensive products i.e. SITC 831, 894, 655, 845, 652, $843,851,656,651$, and 846 . While in 2015, Hong Kong's comparative advantage is dominated by 8 SITC of technology intensive products i.e. SITC 759, 776, 764, 771, 883, 772, 881 and 884. From 1995 to 2005 there was a change in rank position and product group composition, where 2 new SITC emerged in 2005 were SITC 656, 651 and 3 SITC lost from the top-twenty comparative advantages of 1995 i.e. SITC 844, 848, 842. From 2005 to 2015 there was a change in product classification of comparative advantage from unskilled-labor intensive products to technology intensive products.

Table 5. Top-Twenty SITC of South Korea Comparative Advantage 1995, 2005, and 2015

\begin{tabular}{|c|c|c|c|c|}
\hline Year & Rank & SITC & Commodity & RSCA \\
\hline \multirow[t]{20}{*}{1995} & 1 & $\mathrm{~S} 2-883$ & Cinematograph film, exposed and developed & 0.87 \\
\hline & 2 & S2-653 & Fabrics, woven, of man-made fibres (not narrow or special fabrics) & 0.79 \\
\hline & 3 & S2-266 & Synthetic fibres suitable for spinning & 0.77 \\
\hline & 4 & S2-793 & Ships, boats and floating structures & 0.75 \\
\hline & 5 & S2-971 & Gold, non-monetary (excluding gold ores and concentrates) & 0.68 \\
\hline & 6 & $\mathrm{~S} 2-776$ & Thermionic, microcircuits, transistors, valves, etc & 0.62 \\
\hline & 7 & $\mathrm{~S} 2-655$ & Knitted or crocheted fabrics (including tubular, etc, fabrics) & 0.62 \\
\hline & 8 & S2-691 & Structures and parts, nes, of iron, steel or aluminium & 0.61 \\
\hline & 9 & S2-611 & Leather & 0.61 \\
\hline & 10 & S2-786 & Trailers, and other vehicles, not motorized & 0.58 \\
\hline & 11 & S2-656 & Tulle, lace, embroidery, ribbons, trimmings and other small wares & 0.57 \\
\hline & 12 & S2-763 & Gramophones, dictating machines and other sound recorders & 0.56 \\
\hline & 13 & S2-761 & Television receivers & 0.53 \\
\hline & 14 & $\mathrm{~S} 2-847$ & Clothing accessories, of textile fabrics & 0.49 \\
\hline & 15 & $\mathrm{~S} 2-778$ & Electrical machinery and apparatus & 0.48 \\
\hline & 16 & S2-657 & Special textile fabrics and related products & 0.48 \\
\hline & 17 & S2-677 & Iron or steel wire (excluding wire rod), not insulated & 0.45 \\
\hline & 18 & S2-696 & Cutlery & 0.45 \\
\hline & 19 & $\mathrm{~S} 2-511$ & Hydrocarbons, nes, and derivatives & 0.42 \\
\hline & 20 & S2-625 & Rubber tires, tire cases, inner and flaps, for wheels of all kinds & 0.41 \\
\hline \multirow[t]{11}{*}{2005} & 1 & S2-793 & Ships, boats and floating structures & 0.84 \\
\hline & 2 & S2-871 & Optical instruments and apparatus & 0.78 \\
\hline & 3 & S2-266 & Synthetic fibres suitable for spinning & 0.72 \\
\hline & 4 & $\mathrm{~S} 2-655$ & Knitted or crocheted fabrics (including tubular, etc, fabrics) & 0.69 \\
\hline & 5 & $\mathrm{~S} 2-511$ & Hydrocarbons, nes, and derivatives & 0.58 \\
\hline & 6 & $\mathrm{~S} 2-513$ & Carboxylic acids, and their derivatives & 0.57 \\
\hline & 7 & $\mathrm{~S} 2-764$ & Telecommunication equipment, nes; parts and accessories & 0.57 \\
\hline & 8 & S2-656 & Tulle, lace, embroidery, ribbons, trimmings and other small wares & 0.53 \\
\hline & 9 & S2-677 & Iron or steel wire (excluding wire rod), not insulated & 0.51 \\
\hline & 10 & S2-711 & Steam boilers and auxiliary plant: and parts thereof & 0.50 \\
\hline & 11 & $\mathrm{~S} 2-653$ & Fabrics, woven, of man-made fibres (not narrow or special fabrics) & 0.48 \\
\hline
\end{tabular}




\begin{tabular}{ccll}
12 & S2-233 & Synthetic rubber, latex, etc; waste, scrap of unhardened rubber & 0.48 \\
13 & S2-776 & Thermionic, microcircuits, transistors, valves, etc & 0.48 \\
14 & S2-686 & Zinc & 0.43 \\
15 & S2-674 & Universals, plates, and sheets, of iron or steel & 0.42 \\
16 & S2-269 & Old clothing and other old textile articles; rags & 0.40 \\
17 & S2-693 & Wire products (excluding insulated electrical wire); fencing grills & 0.40 \\
18 & S2-724 & Textile and leather machinery, and parts thereof & 0.37 \\
19 & S2-582 & Condensation, polycondensation and polyaddition products & 0.36 \\
\hline 20 & S2-625 & Rubber tires, tire cases, inner and flaps, for wheels of all kinds & 0.35 \\
\hline 1 & S2-793 & Ships, boats and floating structures & 0.83 \\
2 & S2-871 & Optical instruments and apparatus & 0.80 \\
3 & S2-711 & Steam boilers and auxiliary plant; and parts thereof & 0.69 \\
4 & S2-511 & Hydrocarbons, nes, and derivatives & 0.69 \\
5 & S2-266 & Synthetic fibres suitable for spinning & 0.68 \\
6 & S2-233 & Synthetic rubber, latex, etc; waste, scrap of unhardened rubber & 0.60 \\
7 & S2-655 & Knitted or crocheted fabrics (including tubular, etc, fabrics) & 0.55 \\
8 & S2-686 & Zinc & 0.51 \\
9 & S2-674 & Universals, plates, and sheets, of iron or steel & 0.49 \\
10 & S2-685 & Lead & 0.49 \\
11 & S2-776 & Thermionic, microcircuits, transistors, valves, etc & 0.49 \\
12 & S2-513 & Carboxylic acids, and their derivatives & 0.46 \\
13 & S2-672 & Ingots and other primary forms, of iron or steel & 0.45 \\
14 & S2-677 & Iron or steel wire (excluding wire rod), not insulated & 0.43 \\
15 & S2-724 & Textile and leather machinery, and parts thereof & 0.39 \\
16 & S2-778 & Electrical machinery and apparatus & 0.38 \\
17 & S2-269 & Old clothing and other old textile articles; rags & 0.37 \\
18 & S2-582 & Condensation, polycondensation and polyaddition products & 0.36 \\
19 & S2-583 & Polymerization and copolymerization products & 0.35 \\
20 & S2-884 & Optical goods nes & 0.34 \\
\hline
\end{tabular}

Source: UN-COMTRADE 3-digit SITC Revision 2 Authors' calculations.

Table 5 reports the top-twenty comparative advantages of South Korea in 1995 dominated by product groups included in human-capital intensive products classification i.e. SITC 691, 786, 763, 761, 677, 696 and 625. While in 2005, the comparative advantage of South Korea experienced a change that is dominated by product groups included in the classification of technology intensive products of 8 SITC that is SITC 871, 511, 513, 764, $711,776,724$, and 582. Then in 2015, the comparative advantage of South Korea is dominated by technology intensive products with SITC increasing to 10 SITC i.e. SITC 871, 711, 511, 776, 513, 724, 778, 582, 583 and 884. From 1995 to 2005 there was a change in the products classification of comparative advantage from human-capital intensive products to technology intensive products. From 2005 to 2015, South Korea's comparative advantage remained unchanged but there was a change of rank position and product group composition where there were 3 new SITC emerging in 2015 i.e. SITC 778, 583, 884 and 1 SITC missing from top-twenty comparative advantages of 2005 is SITC 764.

Table 6. Top-Twenty SITC of Singapore Comparative Advantage 1995, 2005, and 2015

\begin{tabular}{ccllc}
\hline Year & Rank & SITC & \multicolumn{1}{c}{ Commodity } & RSCA \\
\hline 1995 & 1 & S2-752 & Automatic data processing machines and units thereof & 0.75 \\
& 2 & S2-687 & Tin & 0.73 \\
& 3 & S2-075 & Spices & 0.71 \\
& 4 & S2-763 & Gramophones, dictating machines and other sound recorders & 0.65 \\
& 5 & S2-334 & Petroleum products, refined & 0.63 \\
& 6 & S2-776 & Thermionic, microcircuits, transistors, valves, etc & 0.62 \\
& 7 & S2-762 & Radio-broadcast receivers & 0.61 \\
8 & S2-232 & Natural rubber latex; rubber and gums & 0.61 \\
& S2-759 & Parts, nes of and accessories for machines of headings 751 or 752 & 0.60 \\
& 10 & S2-761 & Television receivers & 0.52 \\
& 11 & S2-431 & Animal and vegetable oils and fats, processed, and waxes & 0.48 \\
12 & S2-686 & Zinc & 0.47 \\
13 & S2-764 & Telecommunication equipment, nes; parts and accessories & 0.41 \\
14 & S2-122 & Tobacco, manufactured & 0.40 \\
15 & S2-277 & Natural abrasives & 0.36 \\
16 & S2-771 & Electric power machinery, and parts thereof & 0.30 \\
17 & S2-716 & Rotating electric plant and parts thereof & 0.30 \\
18 & S2-269 & Old clothing and other old textile articles; rags & 0.29 \\
19 & S2-681 & Silver, platinum and other metals of the platinum group & 0.29 \\
& S2-072 & Cocoa & 0.26 \\
\hline
\end{tabular}




\begin{tabular}{|c|c|c|c|c|}
\hline \multirow[t]{20}{*}{2005} & 1 & S2-687 & Tin & 0.79 \\
\hline & 2 & S2-776 & Thermionic, microcircuits, transistors, valves, etc & 0.76 \\
\hline & 3 & S2-759 & Parts, nes of and accessories for machines of headings 751 or 752 & 0.59 \\
\hline & 4 & $\mathrm{~S} 2-515$ & Organo-inorganic and heterocyclic compounds & 0.58 \\
\hline & 5 & S2-334 & Petroleum products, refined & 0.54 \\
\hline & 6 & S2-277 & Natural abrasives & 0.52 \\
\hline & 7 & S2-898 & Musical instruments, parts and accessories thereof & 0.47 \\
\hline & 8 & S2-752 & Automatic data processing machines and units thereof & 0.45 \\
\hline & 9 & S2-335 & Residual petroleum products, nes and related materials & 0.44 \\
\hline & 10 & S2-723 & Civil engineering, contractors' plant and equipment and parts & 0.36 \\
\hline & 11 & S2-514 & Nitrogen-function compounds & 0.35 \\
\hline & 12 & $\mathrm{~S} 2-511$ & Hydrocarbons, nes, and derivatives & 0.34 \\
\hline & 13 & $\mathrm{~S} 2-512$ & Alcohols, phenols etc, and their derivatives & 0.31 \\
\hline & 14 & S2-895 & Office and stationary supplies & 0.29 \\
\hline & 15 & S2-737 & Metalworking machinery (other than machine-tools), and parts & 0.25 \\
\hline & 16 & S2-764 & Telecommunication equipment, nes; parts and accessories & 0.25 \\
\hline & 17 & S2-882 & Photographic and cinematographic supplies & 0.23 \\
\hline & 18 & S2-762 & Radio-broadcast receivers & 0.22 \\
\hline & 19 & S2-772 & Electrical apparatus for making and breaking electrical circuits & 0.21 \\
\hline & 20 & S2-075 & Spices & 0.20 \\
\hline \multirow[t]{20}{*}{2015} & 1 & S2-687 & Tin & 0.81 \\
\hline & 2 & S2-776 & Thermionic, microcircuits, transistors, valves, etc & 0.75 \\
\hline & 3 & S2-881 & Photographic apparatus and equipment & 0.65 \\
\hline & 4 & S2-898 & Musical instruments, parts and accessories thereof & 0.64 \\
\hline & 5 & S2-683 & Nickel & 0.56 \\
\hline & 6 & S2-334 & Petroleum products, refined & 0.55 \\
\hline & 7 & $\mathrm{~S} 2-514$ & Nitrogen-function compounds & 0.50 \\
\hline & 8 & S2-759 & Parts, nes of and accessories for machines of headings 751 or 752 & 0.45 \\
\hline & 9 & $\mathrm{~S} 2-512$ & Alcohols, phenols etc, and their derivatives & 0.43 \\
\hline & 10 & S2-723 & Civil engineering, contractors' plant and equipment and parts & 0.42 \\
\hline & 11 & S2-277 & Natural abrasives & 0.41 \\
\hline & 12 & $\mathrm{~S} 2-714$ & Engines and motors, non-electric; parts, nes; group 714, item 71888 & 0.40 \\
\hline & 13 & $\mathrm{~S} 2-511$ & Hydrocarbons, nes, and derivatives & 0.37 \\
\hline & 14 & $\mathrm{~S} 2-551$ & Essential oils, perfume and flavour materials & 0.35 \\
\hline & 15 & $\mathrm{~S} 2-122$ & Tobacco, manufactured & 0.35 \\
\hline & 16 & S2-931 & Special transactions, commodity not classified according to class & 0.32 \\
\hline & 17 & S2-728 & Other machinery, equipment, for specialized industries; parts & 0.31 \\
\hline & 18 & S2-553 & Perfumery, cosmetics, toilet preparations, etc & 0.31 \\
\hline & 19 & $\mathrm{~S} 2-583$ & Polymerization and copolymerization products & 0.30 \\
\hline & 20 & $\mathrm{~S} 2-515$ & Organo-inorganic and heterocyclic compounds & 0.30 \\
\hline
\end{tabular}

Source: UN-COMTRADE 3-digit SITC Revision 2 Authors' calculations.

In Singapore (table 6), in 1995 the top-twenty comparative advantages were dominated by the 8 SITC primary products i.e. SITC 075, 334, 232, 431, 122, 277, 269 and 072. In 2005 Singapore's comparative advantage is dominated by 12 SITC technology intensive products, namely SITC 776, 759, 515, 752, 723, 514, 511, 512, 737, 764, 882 and 772. Then in 2015 top-twenty of Singapore's comparative advantage is dominated by technology intensive products as many as 11 SITC are SITC 776, 881, 514, 759, 512, 723, 714, 511, 728, 583, and 515. From 1995 to 2005, there was a change of product classification of comparative advantage from primary products to technology intensive products. While from 2005 to 2015, the comparative advantage remains, but only a change in the rank position and product group composition where there are 4 new SITC emerging in 2015 i.e. SITC 881, 714, 728, 583 and 5 SITC missing from top-twenty comparative advantages of 2005 i.e. SITC 752, 737, 764, 882, 772.

\subsection{Trade Specialization of East Asian Countries}

In this study, referring to Hinloopen and Marrewijk (2005), the trade specialization of East Asian countries determined by calculating the value of export shares from each the East Asian countries (Indonesia, China, Japan, Hong Kong, South Korea, and Singapore). The higher the export share value of a product group, the higher the trade specialization of that product group in a country compared to other product groups in that country.

The export share is calculated by calculating the percentage of a product group (SITC) of a country on the total export value of the country concerned. Higher export share values indicate that the product group is produced in greater proportion than other product groups. After calculating the export share value of 237 SITC, then ranked based on the value of the export share and selected twenty SITC with the highest export share value to serve as trade specialization products of the country concerned. Similar with the determination of comparative advantage, to simplify the interpretation of the results of trade specialization analysis, the authors classified 237 SITC into 6 
classification of products based on the classification of ETA. Table 7-12 shows the top-twenty SITC of East Asian trade specialization in 1995, 2005, and 2015 using the UN-Comtrade data on 3-digit SITC Revision 2 for 237 product groups.

Table 7. Top-Twenty SITC of Indonesia Trade Specialization 1995, 2005, and 2015

\begin{tabular}{|c|c|c|c|c|}
\hline Year & Rank & SITC & Commodity & Export Share $(\%)$ \\
\hline \multirow[t]{20}{*}{1995} & 1 & S2-333 & Crude petroleum and oils obtained from bituminous minerals & 11.330 \\
\hline & 2 & S2-341 & Gas, natural and manufactured & 8.855 \\
\hline & 3 & $\mathrm{~S} 2-634$ & Veneers, plywood, "improved" wood and other wood, worked & 8.423 \\
\hline & 4 & $\mathrm{~S} 2-851$ & Footwear & 4.399 \\
\hline & 5 & $\mathrm{~S} 2-232$ & Natural rubber latex; rubber and gums & 4.324 \\
\hline & 6 & S2-287 & Ores and concentrates of base metals & 4.118 \\
\hline & 7 & S2-334 & Petroleum products, refined & 2.810 \\
\hline & 8 & S2-653 & Fabrics, woven, of man-made fibres (not narrow or special fabrics) & 2.754 \\
\hline & 9 & S2-036 & Crustaceans and molluscs, fresh, chilled, frozen, salted, etc & 2.397 \\
\hline & 10 & $\mathrm{~S} 2-424$ & Other fixed vegetable oils, fluid or solid, crude, refined & 2.278 \\
\hline & 11 & $\mathrm{~S} 2-322$ & Coal, lignite and peat & 2.275 \\
\hline & 12 & $\mathrm{~S} 2-843$ & Womens, girls, infants outerwear, textile, not knitted or crocheted & 1.951 \\
\hline & 13 & $\mathrm{~S} 2-821$ & Furniture and parts thereof & 1.903 \\
\hline & 14 & $\mathrm{~S} 2-635$ & Wood manufactures & 1.843 \\
\hline & 15 & S2-651 & Textile yarn & 1.790 \\
\hline & 16 & $\mathrm{~S} 2-641$ & Paper and paperboard & 1.610 \\
\hline & 17 & $\mathrm{~S} 2-842$ & Men's and boys' outerwear, textile fabrics not knitted or crocheted & 1.609 \\
\hline & 18 & $\mathrm{~S} 2-763$ & Gramophones, dictating machines and other sound recorders & 1.525 \\
\hline & 19 & $\mathrm{~S} 2-845$ & Outerwear knitted or crocheted, not elastic nor rubberized & 1.366 \\
\hline & 20 & $\mathrm{~S} 2-071$ & Coffee and coffee substitutes & 1.352 \\
\hline \multirow[t]{20}{*}{2005} & 1 & S2-341 & Gas, natural and manufactured & 10.686 \\
\hline & 2 & $\mathrm{~S} 2-333$ & Crude petroleum and oils obtained from bituminous minerals & 9.510 \\
\hline & 3 & S2-424 & Other fixed vegetable oils, fluid or solid, crude, refined & 5.561 \\
\hline & 4 & S2-287 & Ores and concentrates of base metals & 5.146 \\
\hline & 5 & $\mathrm{~S} 2-322$ & Coal, lignite and peat & 5.083 \\
\hline & 6 & $\mathrm{~S} 2-232$ & Natural rubber latex; rubber and gums & 3.017 \\
\hline & 7 & $\mathrm{~S} 2-641$ & Paper and paperboard & 2.370 \\
\hline & 8 & $\mathrm{~S} 2-334$ & Petroleum products, refined & 2.234 \\
\hline & 9 & $\mathrm{~S} 2-821$ & Furniture and parts thereof & 2.174 \\
\hline & 10 & $\mathrm{~S} 2-752$ & Automatic data processing machines and units thereof & 2.160 \\
\hline & 11 & $\mathrm{~S} 2-634$ & Veneers, plywood, "improved" wood and other wood, worked & 1.948 \\
\hline & 12 & $\mathrm{~S} 2-651$ & Textile yarn & 1.893 \\
\hline & 13 & $\mathrm{~S} 2-843$ & Womens, girls, infants outerwear, textile, not knitted or crocheted & 1.589 \\
\hline & 14 & $\mathrm{~S} 2-851$ & Footwear & 1.574 \\
\hline & 15 & $\mathrm{~S} 2-763$ & Gramophones, dictating machines and other sound recorders & 1.488 \\
\hline & 16 & S2-682 & Copper & 1.382 \\
\hline & 17 & $\mathrm{~S} 2-764$ & Telecommunication equipment, nes; parts and accessories & 1.350 \\
\hline & 18 & $\mathrm{~S} 2-845$ & Outerwear knitted or crocheted, not elastic nor rubberized & 1.318 \\
\hline & 19 & $\mathrm{~S} 2-778$ & Electrical machinery and apparatus & 1.317 \\
\hline & 20 & S2-772 & Electrical apparatus for making and breaking electrical circuits & 1.316 \\
\hline \multirow[t]{20}{*}{2015} & 1 & $\mathrm{~S} 2-424$ & Other fixed vegetable oils, fluid or solid, crude, refined & 11.815 \\
\hline & 2 & $\mathrm{~S} 2-322$ & Coal, lignite and peat & 10.640 \\
\hline & 3 & $\mathrm{~S} 2-341$ & Gas, natural and manufactured & 6.877 \\
\hline & 4 & $\mathrm{~S} 2-333$ & Crude petroleum and oils obtained from bituminous minerals & 4.309 \\
\hline & 5 & $\mathrm{~S} 2-851$ & Footwear & 2.917 \\
\hline & 6 & $\mathrm{~S} 2-287$ & Ores and concentrates of base metals & 2.746 \\
\hline & 7 & $\mathrm{~S} 2-232$ & Natural rubber latex; rubber and gums & 2.479 \\
\hline & 8 & $\mathrm{~S} 2-897$ & Gold, silver ware, jewelry and articles of precious materials & 2.204 \\
\hline & 9 & S2-641 & Paper and paperboard & 2.128 \\
\hline & 10 & S2-781 & Passenger motor vehicles (excluding buses) & 1.614 \\
\hline & 11 & S2-634 & Veneers, plywood, "improved" wood and other wood, worked & 1.589 \\
\hline & 12 & $\mathrm{~S} 2-651$ & Textile yarn & 1.554 \\
\hline & 13 & $\mathrm{~S} 2-845$ & Outerwear knitted or crocheted, not elastic nor rubberized & 1.547 \\
\hline & 14 & $\mathrm{~S} 2-843$ & Womens, girls, infants outerwear, textile, not knitted or crocheted & 1.258 \\
\hline & 15 & $\mathrm{~S} 2-784$ & Motor vehicle parts and accessories & 1.222 \\
\hline & 16 & $\mathrm{~S} 2-431$ & Animal and vegetable oils and fats, processed, and waxes & 1.168 \\
\hline & 17 & $\mathrm{~S} 2-821$ & Furniture and parts thereof & 1.165 \\
\hline & 18 & $\mathrm{~S} 2-251$ & Pulp and waste paper & 1.149 \\
\hline & 19 & $\mathrm{~S} 2-778$ & Electrical machinery and apparatus & 1.138 \\
\hline & 20 & $\mathrm{~S} 2-625$ & Rubber tires, tire cases, inner and flaps, for wheels of all kinds & 1.072 \\
\hline
\end{tabular}


Source: UN-COMTRADE 3-digit SITC Revision 2 Authors' calculations.

Based on table 7, in 1995 the Indonesian trade specialization was dominated by product groups classified in the primary products of 9 SITC i.e. SITC 333, 341, 232, 287, 334, 036, 424, 322, and 071. In 2005, the trade specialization of Indonesia is still dominated by primary products with the number of SITC declining to 7 SITC namely SITC 341, 333, 424, 287, 322, 232, and 334. Then in 2015, Indonesian trade specialization remains dominated by product groups in primary products classification i.e. SITC 424, 322, 341, 333, 287, 232, 431, and 251 (8 SITC). From 1995 to 2005 there was a change in rank position and product group composition where there were 2 missing SITC of the top-twenty trade specializations of 1995 i.e. SITC 036 and 071 . Then from 2005 to 2015 also changed in rank position and product group composition where there are 2 new SITC, which appear in 2015, i.e. SITC 431, 251 and 1 SITC lost from the top-twenty trade specialization of Indonesia in 2005 that is SITC 334.

Table 8. Top-Twenty SITC of China Trade Specialization 1995, 2005, and 2015

\begin{tabular}{|c|c|c|c|c|}
\hline Year & Rank & SITC & Commodity & Export Share $(\%)$ \\
\hline \multirow[t]{20}{*}{1995} & 1 & S2-843 & Womens, girls, infants outerwear, textile, not knitted or crocheted & 4.223 \\
\hline & 2 & S2-851 & Footwear & 4.217 \\
\hline & 3 & S2-894 & Baby carriages, toys, games and sporting goods & 3.940 \\
\hline & 4 & S2-842 & Men's and boys' outerwear, textile fabrics not knitted or crocheted & 3.524 \\
\hline & 5 & S2-764 & Telecommunication equipment, nes; parts and accessories & 2.718 \\
\hline & 6 & S2-845 & Outerwear knitted or crocheted, not elastic nor rubberized & 2.686 \\
\hline & 7 & S2-652 & Cotton fabrics, woven (not including narrow or special fabrics) & 2.326 \\
\hline & 8 & S2-848 & Articles of apparel, clothing accessories, non-textile, headgear & 1.964 \\
\hline & 9 & S2-846 & Under-garments, knitted or crocheted & 1.958 \\
\hline & 10 & S2-831 & Travel goods, handbags etc, of leather, plastics, textile, others & 1.929 \\
\hline & 11 & S2-899 & Other miscellaneous manufactured articles & 1.822 \\
\hline & 12 & S2-658 & Made-up articles, wholly or chiefly of textile materials & 1.721 \\
\hline & 13 & S2-762 & Radio-broadcast receivers & 1.718 \\
\hline & 14 & S2-653 & Fabrics, woven, of man-made fibres (not narrow or special fabrics) & 1.692 \\
\hline & 15 & S2-893 & Articles, nes of plastic materials & 1.679 \\
\hline & 16 & S2-778 & Electrical machinery and apparatus & 1.607 \\
\hline & 17 & S2-752 & Automatic data processing machines and units thereof & 1.547 \\
\hline & 18 & S2-333 & Crude petroleum and oils obtained from bituminous minerals & 1.503 \\
\hline & 19 & S2-775 & Household type equipment & 1.419 \\
\hline & 20 & S2-651 & Textile yarn & 1.419 \\
\hline \multirow[t]{20}{*}{2005} & 1 & S2-752 & Automatic data processing machines and units thereof & 10.014 \\
\hline & 2 & S2-764 & Telecommunication equipment, nes; parts and accessories & 8.162 \\
\hline & 3 & S2-759 & Parts, nes of and accessories for machines of headings 751 or 752 & 3.898 \\
\hline & 4 & S2-894 & Baby carriages, toys, games and sporting goods & 2.699 \\
\hline & 5 & S2-763 & Gramophones, dictating machines and other sound recorders & 2.681 \\
\hline & 6 & S2-845 & Outerwear knitted or crocheted, not elastic nor rubberized & 2.679 \\
\hline & 7 & S2-776 & Thermionic, microcircuits, transistors, valves, etc & 2.679 \\
\hline & 8 & S2-851 & Footwear & 2.419 \\
\hline & 9 & S2-843 & Womens, girls, infants outerwear, textile, not knitted or crocheted & 2.275 \\
\hline & 10 & S2-821 & Furniture and parts thereof & 2.186 \\
\hline & 11 & S2-778 & Electrical machinery and apparatus & 2.178 \\
\hline & 12 & S2-775 & Household type equipment & 1.989 \\
\hline & 13 & S2-871 & Optical instruments and apparatus & 1.543 \\
\hline & 14 & S2-842 & Men's and boys' outerwear, textile fabrics not knitted or crocheted & 1.535 \\
\hline & 15 & S2-893 & Articles, nes of plastic materials & 1.522 \\
\hline & 16 & S2-772 & Electrical apparatus for making and breaking electrical circuits & 1.466 \\
\hline & 17 & S2-658 & Made-up articles, wholly or chiefly of textile materials & 1.346 \\
\hline & 18 & S2-846 & Under-garments, knitted or crocheted & 1.234 \\
\hline & 19 & S2-699 & Manufactures of base metal & 1.177 \\
\hline & 20 & S2-771 & Electric power machinery, and parts thereof & 1.118 \\
\hline \multirow[t]{11}{*}{2015} & 1 & S2-764 & Telecommunication equipment, nes; parts and accessories & 10.738 \\
\hline & 2 & S2-752 & Automatic data processing machines and units thereof & 6.151 \\
\hline & 3 & S2-776 & Thermionic, microcircuits, transistors, valves, etc & 4.628 \\
\hline & 4 & S2-821 & Furniture and parts thereof & 2.694 \\
\hline & 5 & S2-845 & Outerwear knitted or crocheted, not elastic nor rubberized & 2.543 \\
\hline & 6 & S2-778 & Electrical machinery and apparatus & 2.502 \\
\hline & 7 & S2-851 & Footwear & 2.244 \\
\hline & 8 & S2-894 & Baby carriages, toys, games and sporting goods & 2.010 \\
\hline & 9 & S2-843 & Womens, girls, infants outerwear, textile, not knitted or crocheted & 1.825 \\
\hline & 10 & S2-812 & Sanitary, plumbing, heating, lighting fixtures and fittings & 1.819 \\
\hline & 11 & S2-772 & Electrical apparatus for making and breaking electrical circuits & 1.805 \\
\hline
\end{tabular}




$\begin{array}{llll}12 & \text { S2-775 } & \text { Household type equipment } & 1.765 \\ 13 & \text { S2-893 } & \text { Articles, nes of plastic materials } & 1.757 \\ 14 & \text { S2-759 } & \text { Parts, nes of and accessories for machines of headings 751 or 752 } & 1.603 \\ 15 & \text { S2-871 } & \text { Optical instruments and apparatus } & 1.513 \\ 16 & \text { S2-749 } & \text { Non-electric parts and accessories of machinery } & 1.385 \\ 17 & \text { S2-699 } & \text { Manufactures of base metal } & 1.327 \\ 18 & \text { S2-793 } & \text { Ships, boats and floating structures } & 1.262 \\ 19 & \text { S2-784 } & \text { Motor vehicle parts and accessories } & 1.250 \\ 20 & \text { S2-831 } & \text { Travel goods, handbags etc, of leather, plastics, textile, others } & 1.247\end{array}$

\section{Source: UN-COMTRADE 3-digit SITC Revision 2 Authors' calculations.}

According to table 8 , the Chinese's trade specialization in 1995 was dominated by unskilled-labor intensive products i.e. SITC 843, 851, 894, 842, 845, 652, 848, 846, 831, 658, 653, and 651 (12 SITC). In 2005, China's trade specialization was dominated by technology intensive products with 10 SITC namely SITC 752, 764, 759, 776, 778, 775, 871, 893, 772, and 771. Later in 2015, China's trade specialization is still dominated by technology intensive products as much as 10 SITC i.e. SITC 752, 764, 759, 778, 772, 775, 893, 759, 871, and 749. From 1995 to 2005 there was a change of trade specialization from unskilled-labor intensive products to technology intensive products. Then from 2005 to 2015, China's trade specialization has not changed, but only changing in composition of product groups where there are 2 new SITC emerging in 2015 i.e. SITC 759, 749 and 2 SITC lost from the top-twenty trade specialization of 2005 i.e. SITC 776, 771. For the period 2005 and 2015, the rank on 1-3 of China's trade specializations are occupied by the same product groups i.e. SITC 752, 764 , and 759 .

Table 9. Top-Twenty SITC of Japan Trade Specialization 1995, 2005, and 2015

\begin{tabular}{|c|c|c|c|c|}
\hline Year & Rank & SITC & Commodity & Export Share $(\%)$ \\
\hline \multirow[t]{20}{*}{1995} & 1 & S2-781 & Passenger motor vehicles (excluding buses) & 9.529 \\
\hline & 2 & $\mathrm{~S} 2-776$ & Thermionic, microcircuits, transistors, valves, etc & 9.222 \\
\hline & 3 & S2-784 & Motor vehicle parts and accessories & 4.438 \\
\hline & 4 & S2-764 & Telecommunication equipment, nes; parts and accessories & 4.112 \\
\hline & 5 & $\mathrm{~S} 2-752$ & Automatic data processing machines and units thereof & 3.875 \\
\hline & 6 & S2-759 & Parts, nes of and accessories for machines of headings 751 or 752 & 3.691 \\
\hline & 7 & S2-778 & Electrical machinery and apparatus & 3.258 \\
\hline & 8 & $\mathrm{~S} 2-713$ & Internal combustion piston engines, and parts thereof & 2.962 \\
\hline & 9 & $\mathrm{~S} 2-772$ & Electrical apparatus for making and breaking electrical circuits & 2.582 \\
\hline & 10 & $\mathrm{~S} 2-728$ & Other machinery, equipment, for specialized industries; parts & 2.542 \\
\hline & 11 & S2-793 & Ships, boats and floating structures & 2.468 \\
\hline & 12 & S2-749 & Non-electric parts and accessories of machinery & 2.253 \\
\hline & 13 & S2-674 & Universals, plates, and sheets, of iron or steel & 2.181 \\
\hline & 14 & $\mathrm{~S} 2-782$ & Lorries and special purposes motor vehicles & 2.050 \\
\hline & 15 & S2-931 & Special transactions, commodity not classified according to class & 2.047 \\
\hline & 16 & $\mathrm{~S} 2-874$ & Measuring, checking, analysis, controlling instruments, nes, parts & 1.722 \\
\hline & 17 & $\mathrm{~S} 2-736$ & Metalworking machine-tools, parts and accessories thereof & 1.604 \\
\hline & 18 & $\mathrm{~S} 2-785$ & Cycles, scooters, motorized or not; invalid carriages & 1.310 \\
\hline & 19 & $\mathrm{~S} 2-741$ & Heating and cooling equipment and parts thereof & 1.259 \\
\hline & 20 & S2-763 & Gramophones, dictating machines and other sound recorders & 1.255 \\
\hline \multirow[t]{20}{*}{2005} & 1 & S2-781 & Passenger motor vehicles (excluding buses) & 13.408 \\
\hline & 2 & S2-776 & Thermionic, microcircuits, transistors, valves, etc & 6.704 \\
\hline & 3 & S2-931 & Special transactions, commodity not classified according to class & 4.397 \\
\hline & 4 & S2-784 & Motor vehicle parts and accessories & 4.353 \\
\hline & 5 & S2-778 & Electrical machinery and apparatus & 3.115 \\
\hline & 6 & $\mathrm{~S} 2-728$ & Other machinery, equipment, for specialized industries; parts & 3.102 \\
\hline & 7 & S2-764 & Telecommunication equipment, nes; parts and accessories & 2.921 \\
\hline & 8 & S2-759 & Parts, nes of and accessories for machines of headings 751 or 752 & 2.799 \\
\hline & 9 & $\mathrm{~S} 2-772$ & Electrical apparatus for making and breaking electrical circuits & 2.568 \\
\hline & 10 & $\mathrm{~S} 2-713$ & Internal combustion piston engines, and parts thereof & 2.495 \\
\hline & 11 & $\mathrm{~S} 2-874$ & Measuring, checking, analysis, controlling instruments, parts & 2.207 \\
\hline & 12 & S2-674 & Universals, plates, and sheets, of iron or steel & 2.128 \\
\hline & 13 & S2-749 & Non-electric parts and accessories of machinery & 2.057 \\
\hline & 14 & S2-763 & Gramophones, dictating machines and other sound recorders & 1.991 \\
\hline & 15 & S2-793 & Ships, boats and floating structures & 1.984 \\
\hline & 16 & S2-723 & Civil engineering, contractors' plant and equipment and parts & 1.779 \\
\hline & 17 & S2-736 & Metalworking machine-tools, parts and accessories thereof & 1.630 \\
\hline & 18 & $\mathrm{~S} 2-583$ & Polymerization and copolymerization products & 1.452 \\
\hline & 19 & $\mathrm{~S} 2-782$ & Lorries and special purposes motor vehicles & 1.323 \\
\hline & 20 & $\mathrm{~S} 2-884$ & Optical goods & 1.320 \\
\hline
\end{tabular}




\begin{tabular}{lllll}
\hline 2015 & 1 & S2-781 & Passenger motor vehicles (excluding buses) & 13.762 \\
2 & S2-931 & Special transactions, commodity not classified according to class & 5.927 \\
3 & S2-776 & Thermionic, microcircuits, transistors, valves, etc & 5.177 \\
4 & S2-784 & Motor vehicle parts and accessories & 3.677 \\
5 & S2-728 & Other machinery, equipment, for specialized industries; parts & 3.093 \\
6 & S2-778 & Electrical machinery and apparatus & 2.490 \\
7 & S2-874 & Measuring, checking, analysis, controlling instruments, parts & 2.452 \\
8 & S2-772 & Electrical apparatus for making and breaking electrical circuits & 2.399 \\
9 & S2-749 & Non-electric parts and accessories of machinery & 2.281 \\
10 & S2-713 & Internal combustion piston engines, and parts thereof & 1.990 \\
11 & S2-674 & Universals, plates, and sheets, of iron or steel & 1.825 \\
12 & S2-793 & Ships, boats and floating structures & 1.686 \\
13 & S2-334 & Petroleum products, refined & 1.680 \\
14 & S2-723 & Civil engineering, contractors' plant and equipment and parts & 1.666 \\
15 & S2-759 & Parts, nes of and accessories for machines of headings 751 or 752 & 1.629 \\
16 & S2-583 & Polymerization and copolymerization products & 1.588 \\
17 & S2-782 & Lorries and special purposes motor vehicles & 1.563 \\
18 & S2-736 & Metalworking machine-tools, parts and accessories thereof & 1.471 \\
19 & S2-764 & Telecommunication equipment, nes; parts and accessories & 1.393 \\
\hline
\end{tabular}

Source: UN-COMTRADE 3-digit SITC Revision 2 Authors' calculations.

When viewed from the top-twenty of Japan's trade specializations (table 9) for 1995, 2005, and 2015, the Japan's trade specialization is dominated by technology intensive products classification. In 1995 Japan's trade specialization was dominated by 12 SITC of technology intensive products, namely SITC 776, 764, 752, 759, $778,713,772,728,749,874,736$, and 741 . Then in 2005 , as many as 13 SITC, i.e. SITC $776,778,728,764$, $759,772,713,874,749,723,736,583$ and 884. In 2015 is dominated by 13 SITC i.e. SITC 776, 728, 778, 874, $772,749,713,723,759,583,736,764$, and 598. From 1995 to 2005 there was a change in rank position and product group composition where there were 3 new SITC that emerged in 2005 that were SITC 723, 583, 884 and 2 SITC lost from top-twenty trade specialization in 1995 that is SITC 752 and 741 . Then from 2005 to 2015 also change the position of rank and product group composition where there is 1 new SITC that emerged in 2015 that is SITC 598 and 1 SITC lost from top-twenty of trade specialization in 2005 that is SITC 884. During the period 1995, 2005, and 2015 the first rank of Japan's trade specialization is occupied by the same product group i.e. SITC 781 (Passenger motor vehicles (excluding buses)).

Table 10. Top-Twenty SITC of Hong Kong Trade Specialization 1995, 2005, and 2015

\begin{tabular}{ccclc}
\hline Year & Rank & SITC & \multicolumn{1}{c}{ Commodity } & Export Share (\%) \\
\hline 1995 & 1 & S2-894 & Baby carriages, toys, games and sporting goods & 6.358 \\
& 2 & S2-764 & Telecommunication equipment, nes; parts and accessories & 5.212 \\
& 3 & S2-776 & Thermionic, microcircuits, transistors, valves, etc & 4.357 \\
& 4 & S2-851 & Footwear & 3.257 \\
& 5 & S2-759 & Parts, nes of and accessories for machines of headings 751 or 752 & 3.756 \\
& 6 & S2-845 & Outerwear knitted or crocheted, not elastic nor rubberized & 3.330 \\
& 7 & S2-885 & Watches and clocks & 3.256 \\
& 8 & S2-843 & Womens, girls, infants outerwear, textile, not knitted or crocheted & 2.663 \\
& 9 & S2-831 & Travel goods, handbags etc, of leather, plastics, textile, others & 2.662 \\
10 & S2-583 & Polymerization and copolymerization products & 2.611 \\
& 11 & S2-762 & Radio-broadcast receivers & 1.890 \\
12 & S2-775 & Household type equipment & 1.817 \\
& 13 & S2-893 & Articles, nes of plastic materials & 1.774 \\
14 & S2-653 & Fabrics, woven, of man-made fibres (not narrow or special fabrics) & 1.742 \\
& 15 & S2-842 & Men's and boys' outerwear, textile fabrics not knitted or crocheted & 1.734 \\
16 & S2-899 & Other miscellaneous manufactured articles & 1.719 \\
17 & S2-846 & Under-garments, knitted or crocheted & 1.667 \\
18 & S2-652 & Cotton fabrics, woven (not including narrow or special fabrics) & 1.664 \\
& S2-651 & Textile yarn & 1.632 \\
\hline 20 & S2-778 & Electrical machinery and apparatus & 10.472 \\
& 19 & S2-776 & Thermionic, microcircuits, transistors, valves, etc & 10.086 \\
& 2 & S2-764 & Telecommunication equipment, nes; parts and accessories & 9.352 \\
& S2-759 & Parts, nes of and accessories for machines of headings 751 or 752 & 4.069 \\
& 5 & S2-894 & Baby carriages, toys, games and sporting goods & 3.471 \\
& S2-772 & Electrical apparatus for making and breaking electrical circuits & 3.443 \\
& 7 & S2-845 & Outerwear knitted or crocheted, not elastic nor rubberized & 3.090 \\
& S2-752 & Automatic data processing machines and units thereof & 3.003
\end{tabular}




\begin{tabular}{|c|c|c|c|c|}
\hline & 9 & S2-778 & Electrical machinery and apparatus & 2.676 \\
\hline & 10 & $\mathrm{~S} 2-843$ & Womens, girls, infants outerwear, textile, not knitted or crocheted & 2.544 \\
\hline & 11 & S2-583 & Polymerization and copolymerization products & 2.262 \\
\hline & 12 & S2-771 & Electric power machinery, and parts thereof & 2.064 \\
\hline & 13 & $\mathrm{~S} 2-851$ & Footwear & 1.995 \\
\hline & 14 & S2-885 & Watches and clocks & 1.918 \\
\hline & 15 & S2-667 & Pearl, precious and semi-precious stones, unworked or worked & 1.810 \\
\hline & 16 & $\mathrm{~S} 2-831$ & Travel goods, handbags etc, of leather, plastics, textile, others & 1.652 \\
\hline & 17 & S2-897 & Gold, silver ware, jewelry and articles of precious materials & 1.544 \\
\hline & 18 & $\mathrm{~S} 2-846$ & Under-garments, knitted or crocheted & 1.481 \\
\hline & 19 & S2-651 & Textile yarn & 1.213 \\
\hline & 20 & $\mathrm{~S} 2-652$ & Cotton fabrics, woven (not including narrow or special fabrics) & 1.166 \\
\hline \multirow[t]{20}{*}{2015} & 1 & S2-776 & Thermionic, microcircuits, transistors, valves, etc & 19.088 \\
\hline & 2 & S2-764 & Telecommunication equipment, nes; parts and accessories & 18.142 \\
\hline & 3 & S2-971 & Gold, non-monetary (excluding gold ores and concentrates) & 8.822 \\
\hline & 4 & S2-759 & Parts, nes of and accessories for machines of headings 751 or 752 & 6.017 \\
\hline & 5 & S2-772 & Electrical apparatus for making and breaking electrical circuits & 4.128 \\
\hline & 6 & $\mathrm{~S} 2-752$ & Automatic data processing machines and units thereof & 3.672 \\
\hline & 7 & S2-667 & Pearl, precious and semi-precious stones, unworked or worked & 3.639 \\
\hline & 8 & S2-778 & Electrical machinery and apparatus & 2.461 \\
\hline & 9 & S2-771 & Electric power machinery, and parts thereof & 2.040 \\
\hline & 10 & S2-885 & Watches and clocks & 1.811 \\
\hline & 11 & S2-897 & Gold, silver ware, jewelry and articles of precious materials & 1.682 \\
\hline & 12 & S2-894 & Baby carriages, toys, games and sporting goods & 1.461 \\
\hline & 13 & $\mathrm{~S} 2-845$ & Outerwear knitted or crocheted, not elastic nor rubberized & 1.357 \\
\hline & 14 & $\mathrm{~S} 2-874$ & Measuring, checking, analysis, controlling instruments, parts & 1.134 \\
\hline & 15 & S2-583 & Polymerization and copolymerization products & 1.107 \\
\hline & 16 & $\mathrm{~S} 2-831$ & Travel goods, handbags etc, of leather, plastics, textile, others & 0.930 \\
\hline & 17 & $\mathrm{~S} 2-843$ & Womens, girls, infants outerwear, textile, not knitted or crocheted & 0.761 \\
\hline & 18 & $\mathrm{~S} 2-884$ & Optical goods & 0.758 \\
\hline & 19 & $\mathrm{~S} 2-846$ & Under-garments, knitted or crocheted & 0.741 \\
\hline & 20 & S2-851 & Footwear & 0.701 \\
\hline
\end{tabular}

Source: UN-COMTRADE 3-digit SITC Revision 2 Authors' calculations.

Based on table 10, in 1995 Hong Kong's trade specialization was dominated by unskilled-labor intensive products classification of 10 SITC namely SITC 894, 851, 845, 843, 831, 653, 842, 846, 652 and 651. In 2005 Hong Kong's trade specialization was dominated by 2 product groups: unskilled-labor intensive products and technology intensive products classification with each amount of 8 SITC. Then in 2015 Hong Kong's trade specialization is dominated by 10 SITC of technology intensive products classification i.e. SITC 776, 764, 759, $772,752,778,771,874,583$, and 884 . When viewed from the top-twenty Hong Kong's trade specialization from 1995, 2005, and 2015 there was a change of trade specialization from unskilled-labor intensive products in 1995 to technology intensive products in 2015.

Table 11. Top-Twenty SITC of South Korea Trade Specialization 1995, 2005, and 2015

\begin{tabular}{ccclc}
\hline Year & Rank & SITC & \multicolumn{1}{c}{ Commodity } & Export Share (\%) \\
\hline 1995 & 1 & S2-776 & Thermionic, microcircuits, transistors, valves, etc & 15.491 \\
& 2 & S2-781 & Passenger motor vehicles (excluding buses) & 5.792 \\
& 3 & S2-653 & Fabrics, woven, of man-made fibres (not narrow or special fabrics) & 5.356 \\
& 4 & S2-778 & Electrical machinery and apparatus & 4.443 \\
& 5 & S2-793 & Ships, boats and floating structures & 4.424 \\
& 6 & S2-764 & Telecommunication equipment, nes; parts and accessories & 3.393 \\
& 7 & S2-752 & Automatic data processing machines and units thereof & 3.163 \\
& 8 & S2-583 & Polymerization and copolymerization products & 2.419 \\
& 9 & S2-674 & Universals, plates, and sheets, of iron or steel & 2.105 \\
& 10 & S2-971 & Gold, non-monetary (excluding gold ores and concentrates) & 1.944 \\
& 11 & S2-334 & Petroleum products, refined & 1.844 \\
& 12 & S2-761 & Television receivers & 1.520 \\
& 13 & S2-763 & Gramophones, dictating machines and other sound recorders & 1.459 \\
& 14 & S2-775 & Household type equipment & 1.352 \\
& 15 & S2-611 & Leather & 1.220 \\
& 16 & S2-582 & Condensation, polycondensation and polyaddition products & 1.128 \\
& 17 & S2-898 & Musical instruments, parts and accessories thereof & 1.108 \\
& 18 & S2-691 & Structures and parts, nes, of iron, steel or aluminium & 1.092 \\
& 19 & S2-651 & Textile yarn & 1.068 \\
& 20 & S2-625 & Rubber tires, tire cases, inner and flaps, for wheels of all kinds & 1.063 \\
\hline 2005 & 1 & S2-764 & Telecommunication equipment, nes; parts and accessories & 11.711
\end{tabular}




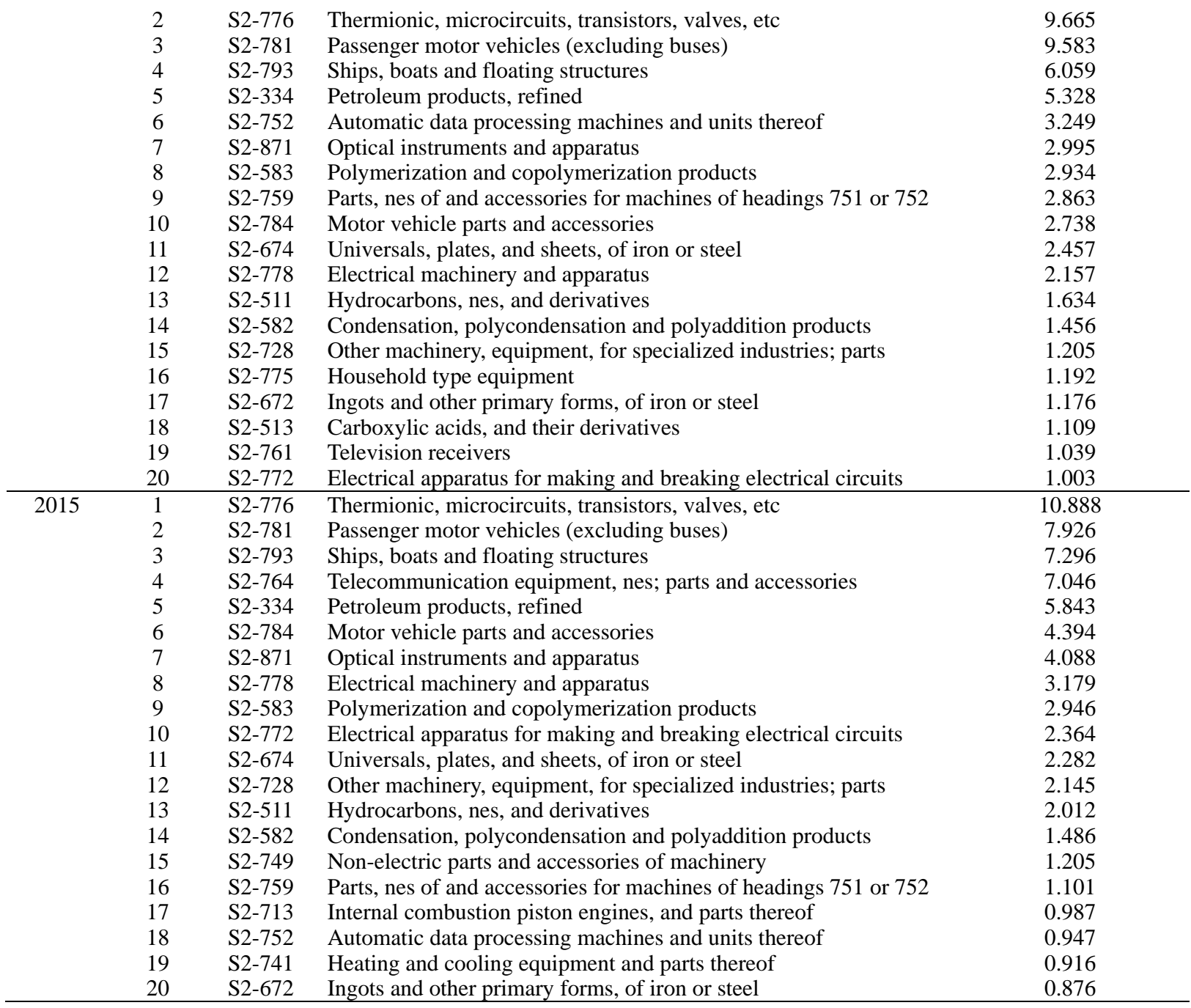

Source: UN-COMTRADE 3-digit SITC Revision 2 Authors' calculations.

South Korea's trade specialization in 1995 was dominated by 2 product groups: technology intensive products and human-capital intensive products (7 SITC). In 2005, South Korea's trade specialization was dominated by technology intensive products with 13 SITC i.e. SITC 764, 776, 752, 871, 583, 759, 778, 511, 582, 728, 775, 513 and 772 . Then in 2015 , South Korea's trade specialization is still dominated by 14 SITC of technology intensive products classification i.e. SITC 776, 764, 871, 778, 583, 772, 728, 511, 582, 749, 759, 713, 752 and 741. From 1995 to 2005, there was a change in product classification of trade specialization from human-capital intensive products to technology intensive products. From 2005 to 2015, the product classification remains fixed but there is a change in rank position and product group composition where there are 3 new SITC that emerged in 2015 i.e. SITC 749, 713, 741 and 2 SITC lost from top-twenty of trade specialization of 2005 i.e. SITC 775, and 513.

Table 12. Top-Twenty SITC of Singapore Trade Specialization 1995, 2005, and 2015

\begin{tabular}{ccclc}
\hline Year & Rank & SITC & \multicolumn{1}{c}{ Commodity } & Export Share (\%) \\
\hline 1995 & 1 & S2-752 & Automatic data processing machines and units thereof & 16.521 \\
& 2 & S2-776 & Thermionic, microcircuits, transistors, valves, etc & 15.552 \\
& 3 & S2-759 & Parts, nes of and accessories for machines of headings 751 or 752 & 7.526 \\
& 4 & S2-334 & Petroleum products, refined & 6.559 \\
& 5 & S2-764 & Telecommunication equipment, nes; parts and accessories & 5.813 \\
& 6 & S2-931 & Special transactions, commodity not classified according to class & 2.232 \\
& 7 & S2-778 & Electrical machinery and apparatus & 2.135 \\
& S2-772 & Electrical apparatus for making and breaking electrical circuits & 2.073 \\
9 & S2-763 & Gramophones, dictating machines and other sound recorders & 1.913 \\
& 10 & S2-762 & Radio-broadcast receivers & 1.775 \\
& S2-761 & Television receivers & 1.464 \\
& 11 & S2-749 & Non-electric parts and accessories of machinery & 1.082 \\
13 & S2-716 & Rotating electric plant and parts thereof & 0.950
\end{tabular}




\begin{tabular}{|c|c|c|c|c|}
\hline & 14 & S2-583 & Polymerization and copolymerization products & 0.899 \\
\hline & 15 & S2-771 & Electric power machinery, and parts thereof & 0.885 \\
\hline & 16 & S2-723 & Civil engineering, contractors' plant and equipment and parts & 0.864 \\
\hline & 17 & S2-728 & Other machinery, equipment, for specialized industries; parts & 0.859 \\
\hline & 18 & S2-122 & Tobacco, manufactured & 0.844 \\
\hline & 19 & S2-515 & Organo-inorganic and heterocyclic compounds & 0.773 \\
\hline & 20 & S2-874 & Measuring, checking, analysis, controlling instruments, parts & 0.733 \\
\hline \multirow[t]{20}{*}{2005} & 1 & S2-776 & Thermionic, microcircuits, transistors, valves, etc & 23.456 \\
\hline & 2 & S2-334 & Petroleum products, refined & 11.584 \\
\hline & 3 & S2-759 & Parts, nes of and accessories for machines of headings 751 or 752 & 7.172 \\
\hline & 4 & S2-752 & Automatic data processing machines and units thereof & 6.775 \\
\hline & 5 & S2-764 & Telecommunication equipment, nes; parts and accessories & 5.657 \\
\hline & 6 & S2-931 & Special transactions, commodity not classified according to class & 3.787 \\
\hline & 7 & S2-772 & Electrical apparatus for making and breaking electrical circuits & 2.111 \\
\hline & 8 & S2-778 & Electrical machinery and apparatus & 2.071 \\
\hline & 9 & S2-515 & Organo-inorganic and heterocyclic compounds & 2.061 \\
\hline & 10 & S2-583 & Polymerization and copolymerization products & 1.573 \\
\hline & 11 & S2-723 & Civil engineering, contractors' plant and equipment and parts & 1.569 \\
\hline & 12 & S2-898 & Musical instruments, parts and accessories thereof & 1.329 \\
\hline & 13 & S2-541 & Medicinal and pharmaceutical products & 1.282 \\
\hline & 14 & S2-749 & Non-electric parts and accessories of machinery & 1.122 \\
\hline & 15 & S2-514 & Nitrogen-function compounds & 1.059 \\
\hline & 16 & S2-874 & Measuring, checking, analysis, controlling instruments, parts & 1.033 \\
\hline & 17 & S2-511 & Hydrocarbons, nes, and derivatives & 0.947 \\
\hline & 18 & S2-582 & Condensation, polycondensation and polyaddition products & 0.917 \\
\hline & 19 & S2-598 & Miscellaneous chemical products & 0.762 \\
\hline & 20 & S2-667 & Pearl, precious and semi-precious stones, unworked or worked & 0.733 \\
\hline \multirow[t]{21}{*}{2015} & 1 & S2-776 & Thermionic, microcircuits, transistors, valves, etc & 24.375 \\
\hline & 2 & S2-334 & Petroleum products, refined & 12.167 \\
\hline & 3 & S2-931 & Special transactions, commodity not classified according to class & 5.723 \\
\hline & 4 & S2-764 & Telecommunication equipment, nes; parts and accessories & 3.476 \\
\hline & 5 & S2-752 & Automatic data processing machines and units thereof & 2.980 \\
\hline & 6 & S2-759 & Parts, nes of and accessories for machines of headings 751 or 752 & 2.742 \\
\hline & 7 & S2-583 & Polymerization and copolymerization products & 2.728 \\
\hline & 8 & S2-541 & Medicinal and pharmaceutical products & 2.194 \\
\hline & 9 & S2-874 & Measuring, checking, analysis, controlling instruments, parts & 2.111 \\
\hline & 10 & S2-728 & Other machinery, equipment, for specialized industries; parts & 2.102 \\
\hline & 11 & S2-778 & Electrical machinery and apparatus & 1.959 \\
\hline & 12 & S2-792 & Aircraft and associated equipment, and parts thereof & 1.855 \\
\hline & 13 & S2-772 & Electrical apparatus for making and breaking electrical circuits & 1.536 \\
\hline & 14 & S2-723 & Civil engineering, contractors' plant and equipment and parts & 1.460 \\
\hline & & & Engines and motors, non-electric; parts, nes; group 714 , item & \\
\hline & 15 & S2-714 & 71888 & 1.423 \\
\hline & 16 & S2-598 & Miscellaneous chemical products & 1.339 \\
\hline & 17 & S2-898 & Musical instruments, parts and accessories thereof & 1.314 \\
\hline & 18 & S2-514 & Nitrogen-function compounds & 1.171 \\
\hline & 19 & S2-515 & Organo-inorganic and heterocyclic compounds & 1.057 \\
\hline & 20 & S2-749 & Non-electric parts and accessories of machinery & 0.998 \\
\hline
\end{tabular}

Source: UN-COMTRADE 3-digit SITC Revision 2 Authors' calculations.

In 1995, Singapore's trade specialization was dominated by 14 SITC of technology intensive products classification i.e. SITC 752, 776, 759, 764, 778, 772, 749, 716, 583, 771, 723, 728, 515 and 874. In 2005, Singapore's trade specialization was still dominated by technology intensive products with 16 SITC namely SITC 776, 759, 752, 764, 772, 778, 515, 583, 723, 541, 749, 514, 874, 511, 582 and 598. Then in 2015, the Singapore's trade specialization is still dominated by technology intensive products classification with an increasing number of SITC to 17 SITC namely SITC 776, 764, 752, 759, 583, 541, 874, 728 , 778, 792, 772, 723, $714,598,514,515$, and 749. From 1995 to 2005, there was a change of rank position and product group composition where 5 new SITC emerged in 2005 were SITC 541, 514, 511, 582, 598 and 3 SITC are missing from top-twenty of trade specialization in 1995 that is SITC 716, 771, 728. Then from 2005 to 2015 also change in position of rank and product group composition where there are 3 new SITC that appear in 2015 that is SITC $728,792,714$ and 2 SITC which missing from the top-twenty of trade specializations in 2005 i.e. SITC 511 and 582.

\subsection{Do East Asian Countries Specialize in Product Groups with High Comparative Advantage?}

During the period 1995, 2005, and 2015, based on the top-twenty of Indonesia's comparative advantages and 
trade specialization, the comparative advantages and trade specialization of Indonesia are on the classification of primary products but not all of the product groups that constitute Indonesia's comparative advantage is as Indonesia's trade specialization. In 1995, the proportion of Indonesian trade specialization which is a comparative advantage is $65 \%$, from 20 SITC of high comparative advantage only 13 SITC are used as trade specialization of Indonesia. In 2005, Indonesia did not specialize in products with high comparative advantages due to the proportion of product groups in Indonesian trade specialization which is a comparative advantage of Indonesia only $35 \%$, from 20 SITC of Indonesia comparative advantage is only 7 SITC become the Indonesian's trade specialization namely SITC 341, 424, 287, 322, 232, 634, 651. Then in 2015 Indonesia still does not specialize in product groups with high comparative advantage, where the proportion of Indonesian trade specialization which is a comparative advantage of Indonesia is only $50 \%$ i.e. only 10 SITC Indonesia's trade specialization with high comparative advantage, that is SITC 424, 322, 341, 851, 287, 232, 634, 651, 431, 251.

China's comparative advantages and trade specialization in 1995 was in unskilled-labor intensive products classification, but the product group that China's comparative advantage has not all become into trade specialization, the proportion of China's comparative advantage that is China's trade specialization is $45 \%$, from 20 SITC with high comparative advantage, only 9 SITC are used as China's trade specialization. For 2005 and 2015, the product group that became China's comparative advantage was not used as a Chinese trade specialization, where China's comparative advantages in 2005 and 2015 were dominated by unskilled-labor intensive products but Chinese trade specialization in the same year was dominated by technology intensive products. In 2005 and 2015, the proportion of China's trade specialization which is a comparative advantage is $40 \%$, from 20 SITCs in Chinese trade specialization only 8 SITC with high comparative advantages. For 2005 were SITC 763, 658, 894, 851, 845, 752, 871, and 842 while for 2015 were SITC 812, 845, 831, 851, 894, 752, 843 , and 764 .

Based on the top-twenty Japan's comparative advantages and trade specialization, during the 1995, 2005, and 2015, the comparative advantages and trade specialization of Japan is on the technology intensive products classification. Despite the comparative advantages and trade specialization of Japan in the classification of technology, intensive products but not all of the product groups that become comparative advantages become the trade specialization. In 1995 and 2005, from 20 SITC with high comparative advantages, only 10 SITC were used as Japan's trade specializations. In 2015 Japan did not specialize in products with high comparative advantages because the proportion of Japan product group which is a comparative advantage is only $30 \%$ from 20 SITC of comparative advantage only 6 SITC become as trade specialization, that is SITC 736, 728, 781, 723, 674, and 713 .

From the results of Hong Kong's comparative advantage analysis and trade specialization for the period of 1995 and 2005 is on the unskilled-labor intensive products classification but not all product groups of comparative advantages become as trade specialization, where from 20 SITC comparative advantage only 11 SITC, which serve as trade specialization in 1995, and 13 SITC in 2005. In 2015, there was a change in the classification of comparative advantages and trade specialization from unskilled-labor intensive products to technology intensive products but it is the same as 1995 and 2005, that in 2015 not all of the product groups on comparative advantage become the trade specialization, from 20 SITC comparative advantage only 12 SITC which serve as a Hong Kong's trade specialization.

South Korea in 1995 has not fully specialized in product groups with high comparative advantages, in which South Korea's comparative advantage in 1995 was dominated by human-capital intensive products but South Korea's trade specialization in the same year was dominated by technology intensive products and human-capital intensive products. The product group that became a comparative advantage of South Korea is not all of them as trade specialization, where from 20 SITC with high comparative advantages, only 10 SITC are used as South Korea's trade specialization. In 2005 and 2015, although South Korea's comparative advantage and trade specialization were in the classification of technology intensive products but not all of the comparative advantage were made as trade specialization, where from 20 SITC comparative advantages in 2005 only 8 SITC $(40 \%)$ of South Korea's trade specialization has a high comparative advantage, namely SITC 793, 871, 511, 513, $764,776,674,582$ and by 2015 only 9 SITC $(45 \%)$ of South Korean trade specialization with high comparative advantages i.e. SITC 793, 871, 511, 674, 776, 672, 778, 582, and 583.

Based on the top-twenty comparative advantage and trade specialization of Singapore, in 1995 the product group that became Singapore's comparative advantage was not used as a trade specialization, where Singapore's comparative advantage was dominated by primary products but Singapore's trade specialization was dominated by technology intensive products. In 2005 and 2015, although Singapore's comparative advantages and trade specialization were in the classification of technology intensive products but not all of the product groups that 
became comparative advantages were made as trade specializations. During the period of 1995, 2005, and 2015, the proportion of Singapore's trade specialization, which is Singapore's comparative advantage, is only $55 \%$ of the 20 SITC with high comparative advantage, only 11 SITC are made as Singapore's trade specialization.

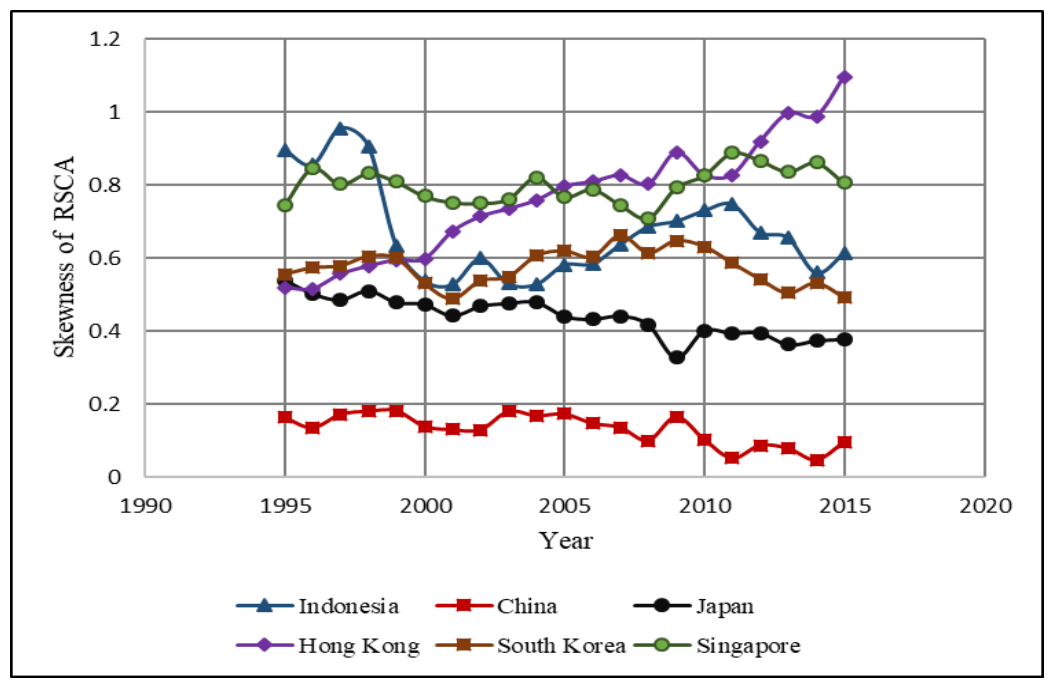

Source: UN-COMTRADE 3-digit SITC Revision 2. Authors' calculation.

Figure 3. Trends in Skewness of Comparative Advantages from East Asian Countries, 1995-2015

The positive value of skewness on RSCA coefficient indicates that a country specializes more on products that have low comparative advantages. While the negative value of RSCA skewness coefficient indicates that a country specializes more on products with high comparative advantage (Widodo, 2010). From Figure 3 above, it is shown that all East Asian countries (Indonesia, China, Japan, Hong Kong, South Korea, and Singapore) have positive values of skewness coefficient, indicating that Indonesia, China, Japan, Hong Kong, South Korea, and Singapore specialize in product groups with low comparative advantages.

\section{Conclusions}

During the 1995, 2005, and 2015 study periods, East Asian countries (Indonesia, China, Japan, Hong Kong, South Korea, and Singapore) specialize in products with low comparative advantages where not all product groups that become comparative advantages serve as trade specialization. Throughout the study period, it was found that technology intensive products are a classification of product groups that dominate comparative advantage and trade specialization of East Asian countries. This result is also supported by a positive value of skewness, indicating that during the period 1995-2015, Indonesia, China, Japan, Hong Kong, South Korea, and Singapore specialize in product groups with low comparative advantages.

\section{References}

Amiti, M. (1999). Specialization Patterns in Europe. Weltwirtschaftliches Archiv, Bd.135, H.4, pp.573-593. https://doi.org/10.1007/BF02707385

Appleyard, D. R., Field, Jr. A. J., \& Cobb, S. L. (2008). International Economics. Sixth Edition. McGraw-Hill Companies, Inc.

Balassa, B. (1977). Revealed Comparative Advantage revisited: an analysis of relative export shares of the industrial countries, 1953-1971. The Johns Hopkins University, The Manchester School. https://doi.org/10.1111/j.1467-9957.1977.tb00701.x

Balassa, B., \& Noland, M. (1989). Revealed Comparative Advantage in Japan and the United States. Journal of International Economic Integration, 4(2), Autumn 1989, 8-22. https://doi.org/10.11130/jei.1989.4.2.8

Bojnec, S. (2001). Trade and Revealed Comparative Advantage measures: Regional and Central and East European agricultural trade. Eastern European Economics, 39(2), 72-98. https://doi.org/10.1080/00128775.2001.11040990

Caves, R. E., Frankel, J. A., \& Jones. R. W. (1993). World Trade and Payments. Sixth Edition. Harper Collins College Publishers.

Ferrarini, B., \& Scaramozzino, P. (2010). Indicator and patterns of specialization in international trade. Working 
paper, no.2011/10.

Ferto, I., \& Soos, K. (2008). Trade specialization in the European Union and in Postcommunist European countries. Eastern European Economics, 46(3), 5-28. https://doi.org/10.2753/EEE0012-8775460301

Hinloopen, J., \& Marrewijk, C. (2005). Empirical relevance of the Hilman Condition for Revealed Comparative Advantage: 10 stylized facts. Utrecht School of Economics, Tjalling C. Koopmans Research Institute, Discussion Paper Series, 05-24.

Isogai, T., Morishita, H., \& Ruffer. R. (2002). Analysis of intra-and inter-regional trade in East Asia: comparative advantage structure and dynamic interdependency in trade flows. International Department Working Paper Series. 02-E-1. Bank of Tokyo.

Krugman, P. R., \& Maurice, O. (2009). International Economics-Theory and Policy. 8th Edition. Pearson-Addison Wesley.

Laursen, K. (1998). Revealed Comparative Advantage and the alternatives as measures of international specialisation. Danish research Unit for Industrial Dynamics (DRUID) Working Paper, no. 98-30.

Lederman, D., Olarreaga, M., \& Rubiano, E. (2008). Trade specialization in Latin America: the impact of China and India. Review of World Economics, 144(2), 248-271. https://doi.org/10.1007/s10290-008-0146-z

Lind, D. A., Marchal, W. G., \& Wathen, S. A. (2014). Statistical Techniques in Business \& Economics. Fifteenth Edition. McGraw-Hill.

Markusen, J. R., Melvin, J. R., Kaempfer, W. H., \& Maskus, K. E. (1995). International trade theory and evidence. International Edition. McGraw-Hill, Inc.

Minondo, A. (2011). Does Comparative Advantage explain countries' diversification level? Review of World Economics, 147(3), 507-526. https://doi.org/10.1007/s10290-011-0097-7

Phuong, Q. L. (2010). Evaluating Vietnam's changing comparative advantage patterns. ASEAN Economic Bulletin, 27(2), 221-230. https://doi.org/10.1355/ae27-2e

Porter, M. E. (1990). The Competitive Advantage of Nations. Second Edition. Free Press, University of California. https://doi.org/10.1007/978-1-349-11336-1

Salvatore, D. (2004). International Economics. Eighth Edition. John Wiley \& Sons, Inc.

Todaro, M. P., \& Stephen C. S. (2015). Economic Development. 12th Edition. Pearson Education, Inc.

Vavryshchuk, V. (2008). Ukraine's Trade Specialization-What Revealed Comparative Advantages Have to Say. Problems of Economic Transition, 50(7), November 2007, 37-45.

Wang, J. C. F. (1997). Comparative Asian Politics. Prentice Hall International.

Widodo, T. (2012). Unbalanced economic growth and dynamic trade specialization. Journal of Center for World Trade Studies.

Widodo, T. (2009a). Comparative advantage: Theory, empirical measures and case studies. Review of Economic and Business Studies (REBS), 4, 57-82.

Widodo, T. (2009b). Dynamic Comparative Advantage in the ASEAN+3. Journal of Economic Integration, 24(3), 505-529. https://doi.org/10.11130/jei.2009.24.3.505

Widodo, T. (2010). Book Manuscript: International trade, regionalism and dynamic market. BPFE Yogyakarta.

WITS (World Integrated Trade Solution) 2010, 2011, 2012, 2013, 2014.

World Bank. (2003). World Development Report 2003, Washington DC: The World Bank. World Development Indicators (WDI) 2014.

Yilmaz, B. (2005). The foreign trade pattern and foreign trade specialization in the European Union: a comparison of six new member/ candidate countries and the EU/ 15. Eastern European Economics, 43(5), 74-100. https://doi.org/10.1080/00128775.2005.11041118

Yue, C., \& Hua, P. (2002). Does comparative advantage explains export patterns in China? China Economic Review, 13, 276-296. https://doi.org/10.1016/S1043-951X(02)00073-1 


\section{Appendix A}

Classification by Empirical Trade Analysis (ETA)

\begin{tabular}{|c|c|c|c|}
\hline No & Product Classification & Amount of SITC & The 3-digit SITC Revision 2 \\
\hline 1 & Primary Products & 83 & 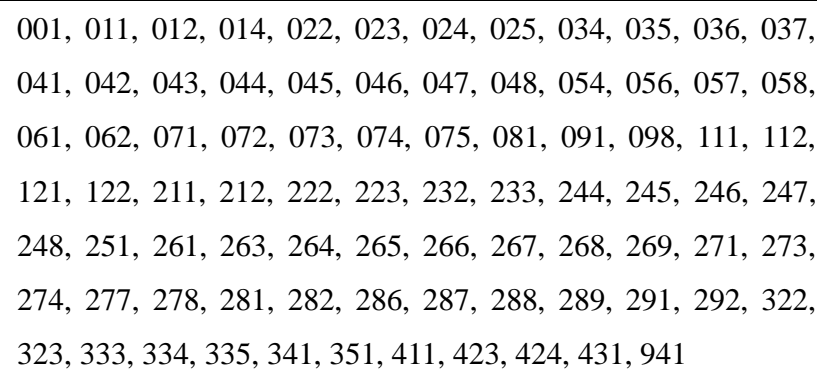 \\
\hline 2 & $\begin{array}{l}\text { Natural-resource intensive } \\
\text { products }\end{array}$ & 21 & $\begin{array}{l}524,611,612,613,633,634,635,661,662,663,667,671, \\
681,682,683,684,685,686,687,688,689\end{array}$ \\
\hline 3 & $\begin{array}{l}\text { Unskilled-labor } \\
\text { products }\end{array}$ & 26 & $\begin{array}{l}651,652,653,654,655,656,657,658,659,664,665,666, \\
793,812,821,831,842,843,844,845,846,847,848,851, \\
894,895\end{array}$ \\
\hline 4 & $\begin{array}{l}\text { Technology } \\
\text { products }\end{array}$ & 62 & $\begin{array}{l}511,512,513,514,515,516,522,523,541,562,572,582, \\
583,584,585,591,592,598,711,712,713,714,716,718, \\
721,722,723,724,725,726,727,728,736,737,741,742, \\
743,744,745,749,751,752,759,764,771,772,773,774, \\
775,776,778,792,871,872,873,874,881,882,883,884, \\
893,951\end{array}$ \\
\hline 5 & $\begin{array}{l}\text { Human-capital } \\
\text { products }\end{array}$ & 43 & $\begin{array}{l}531,532,533,551,553,554,621,625,628,641,642,672, \\
673,674,675,676,677,678,679,691,692,693,694,695, \\
696,697,699,761,762,763,781,782,783,784,785,786, \\
791,885,892,896,897,898,899\end{array}$ \\
\hline 6 & Not classified & 5 & $911,931,961,971,999$ \\
\hline
\end{tabular}

Source: http://www2.econ.uu.nl/users/marrewijk/eta/

\section{Copyrights}

Copyright for this article is retained by the author(s), with first publication rights granted to the journal.

This is an open-access article distributed under the terms and conditions of the Creative Commons Attribution license (http://creativecommons.org/licenses/by/4.0/). 